\title{
How significant is submarine groundwater discharge and its associated dissolved inorganic carbon in a river-dominated shelf system?
}

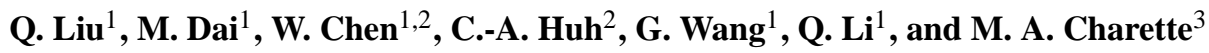 \\ ${ }^{1}$ State Key Laboratory of Marine Environmental Science, Xiamen University, Xiamen, China \\ ${ }^{2}$ Institute of Earth Sciences, Academia Sinica, Taipei \\ ${ }^{3}$ Department of Marine Chemistry and Geochemistry, Woods Hole Oceanographic Institution, Woods Hole, MA, USA \\ Correspondence to: M. Dai (mdai@xmu.edu.cn)
}

Received: 14 November 2011 - Published in Biogeosciences Discuss.: 21 December 2011

Revised: 4 April 2012 - Accepted: 20 April 2012 - Published: 22 May 2012

\begin{abstract}
In order to assess the role of submarine groundwater discharge (SGD) and its impact on the carbonate system on the northern South China Sea (NSCS) shelf, we measured seawater concentrations of four radium isotopes $223,224,226,228 \mathrm{Ra}$ along with carbonate system parameters in June-July, 2008. Complementary groundwater sampling was conducted in coastal areas in December 2008 and October 2010 to constrain the groundwater end-members. The distribution of Ra isotopes in the NSCS was largely controlled by the Pearl River plume and coastal upwelling. Long-lived $\mathrm{Ra}$ isotopes $\left({ }^{228} \mathrm{Ra}\right.$ and $\left.{ }^{226} \mathrm{Ra}\right)$ were enriched in the river plume but low in the offshore surface water and subsurface water/upwelling zone. In contrast, short-lived Ra isotopes $\left({ }^{224} \mathrm{Ra}\right.$ and ${ }^{223} \mathrm{Ra}$ ) were elevated in the subsurface water/upwelling zone as well as in the river plume but depleted in the offshore surface water. In order to quantify SGD, we adopted two independent mathematical approaches. Using a three end-member mixing model with total alkalinity (TAlk) and Ra isotopes, we derived a SGD flux into the NSCS shelf of $2.3-3.7 \times 10^{8} \mathrm{~m}^{3} \mathrm{day}^{-1}$. Our second approach involved a simple mass balance of ${ }^{228} \mathrm{Ra}$ and ${ }^{226} \mathrm{Ra}$ and resulted in a first order but consistent SGD flux estimate of $2.2-3.7 \times 10^{8} \mathrm{~m}^{3} \mathrm{day}^{-1}$. These fluxes were equivalent to $12-21 \%$ of the Pearl River discharge, but the source of the SGD was mostly recirculated seawater. Despite the relatively small SGD volume flow compared to the river, the associated material fluxes were substantial given their elevated concentrations of dissolved inorganic solutes. In this case, dissolved inorganic carbon (DIC) flux through SGD
\end{abstract}

was $153-347 \times 10^{9} \mathrm{~mol} \mathrm{yr}^{-1}$, or $\sim 23-53 \%$ of the riverine DIC export flux. Our estimates of the groundwater-derived phosphate flux ranged $3-68 \times 10^{7} \mathrm{~mol} \mathrm{yr}^{-1}$, which may be responsible for new production on the shelf up to 0.3 $6.3 \mathrm{mmol} \mathrm{C} \mathrm{m}^{-2} \mathrm{~d}^{-1}$. This rate of new production would at most consume $11 \%$ of the DIC contribution delivered by SGD. Hence, SGD may play an important role in the carbon balance over the NSCS shelf.

\section{Introduction}

Recent studies have recognized SGD as an important component of the hydrological cycle and chemical budgets in the coastal zone (Swarzenski et al., 2001; Taniguchi et al., 2002; Burnett et al., 2003; Charette et al., 2003; Moore, 2003; Bokuniewicz et al., 2008). Moore et al. (2008) estimated that the SGD flux to the Atlantic Ocean is similar in volume to the riverine flux. SGD is often characterized by high concentrations of nutrients, trace metals and inorganic carbon as compared with surface water. Inputs of these materials can have a profound impact on the biogeochemistry and ecosystem functioning of coastal systems (Moore, 2010a). In particular, SGD has been shown to be an important nutrient source to estuaries, salt marshes, oceanic islands, and coral reefs (Marsh, 1977; Johannes, 1980; Capone and Bautista, 1985; Charette and Buesseler, 2004; Charette, 2007; Santos et al., 2008; Burnett et al., 2009; Garcia-Solsona et al., 2010; Kim et al., 2011). As a consequence, studies have suggested a 
linkage between SGD and coastal eutrophication and harmful algae bloom outbreaks (Hu et al., 2006; Lee and Kim, 2007; Lee et al., 2010). Cai et al. (2003) reported extremely high partial pressure of $\mathrm{CO}_{2}\left(p \mathrm{CO}_{2}\right)$ and DIC in coastal wells along South Carolina, US and they estimated that the DIC flux associated with SGD to these coastal waters was comparable to the contribution of nearby river systems.

While it is clear that many coastal systems are impacted by SGD, its influence on river-dominated ocean margins (RioMar) is less well known, mainly because material inputs from river plumes are substantial and mixing between different fluid sources is often complex. One of the challenges is that river plumes very often possess the same geochemical signals as SGD. While studies in the Mississippi, Atchafalaya, Chao Phraya estuaries, Yellow River delta, and Changjiang plume using $\mathrm{Ra}$ isotopes (Krest et al., 1999; Moore and Krest, 2004; Dulaiova and Burnett, 2006; Peterson et al., 2008a; Gu et al., 2012) have already suggested its overall importance, quantitative SGD estimates remain difficult in these systems.

The NSCS is a major river-dominated shelf margin (Dagg et al., 2008). The strong river plume is generated from the Pearl River, which is typically transported in summer eastward due to the southwestern monsoon (Gan et al., 2009b). Meanwhile, wind and topographically induced coastal upwelling (Gan et al., 2009a; Shu et al., 2011a) interacted with the river plume (Gan et al., 2009b) and shaped much of the summertime circulation on the NSCS shelf. In the backdrop of the hydrodynamics is the strong biological production with the associated nutrient and inorganic carbon consumption (Dai et al., 2008; Cao et al., 2011; Han et al., 2012). However, we still know little about the role of SGD in the biogeochemistry of this complex system.

In this paper we examined the SGD based on a high spatial resolution sampling of $\mathrm{Ra}$ radioisotopes and the carbonate system parameters in summer time in this major river dominated margin system. We adopted two independent mathematical approaches, which resulted in consistent SGD. Based on these results we estimated the SGD contribution to the DIC budget in the NSCS relative to the Pearl River. These results provide insights into the impact of SGD on the carbon budget on a river-dominated shelf which is also influenced by coastal upwelling.

\section{Materials and methods}

\subsection{Study area}

The NSCS (Fig. 1) is influenced by coastal upwelling induced by the prevailing southwesterly winds and intensified by the topography of the eastward widened shelf in summer (Gan et al., 2009a). The Pearl River is the largest river in southern China with $80 \%$ of its discharge into the South China Sea (SCS) taking place in the southwestern monsoon dominated wet season (April-September) (Guo et al., 2008). The river has three major tributaries (i.e. the West River, the North River, and the East River) and several small local tributaries. The Pearl River estuary (PRE) has three sub-estuaries: Lingdingyang, Modaomen and Huangmaohai. This study focuses on the Lingdingyang, which is traditionally regarded as the PRE (Guo et al., 2008). After leaving the PRE, the river plume expands eastward to the NSCS with the wind-induced upwelling resulting in a widened and thickened buoyant plume over the shelf in summer (Gan et al., 2009b). The surface sediments across the NSCS continental shelf show grain size gradations, from gravel inshore to silt offshore. The sediments consist of both terrigenous and biogenous detritus, as well as small amounts of authigenic minerals (Luo et al., 1985; Zhang et al., 2003). The region along the shoreline of the NSCS is composed of thick and widespread Quaternary deposits (Chen, 2008). The delta plain is formed by thick sediments of alternating marine and fluvial facies containing numerous unconfined and confined groundwater aquifers (Chen, 2008). The aquifer in the littoral plain is a sandy lens up to $20 \mathrm{~m}$ thick, which constitutes the water source to the coastal residents and fishing ports (Liao et al., 2005; Chen, 2008).

\subsection{Sampling and measurements}

Our cruise, which was organized under the South China Sea Coastal Oceanographic Process Experiment (SCOPE), was carried out from 30 June to 8 July, 2008 (Leg 1) onboard the R/V Shiyan III. The cruise began from the PRE, and continued on to the east of Taiwan Shoal in the NSCS, where water depths and distance offshore ranged from 25 to $350 \mathrm{~m}$ and 15 to $180 \mathrm{~km}$, respectively (Fig. 1). Samples used for this study were collected along seven cross-shelf transects (designated as 1-7). Large-volume samples (from 50 L nearshore to $100 \mathrm{~L}$ offshore) for Ra isotopes were pumped from $\sim 5 \mathrm{~m}$ below the surface by a submersible pump through a $1 \mu \mathrm{m}$ cartridge filter and then into a polypropylene container. Subsurface seawater samples were taken by $30 \mathrm{~L}$ Niskin bottles mounted on a Rosette sampler equipped with a calibrated SBE-19-plus Conductivity-Temperature-Depth (CTD) recorder (Sea-Bird Co.) that measured water temperature and salinity. Detailed cruise information has been reported in Cao et al. (2011).

In addition to seawater collection from the cruise, we sampled coastal groundwater and spring water along the NSCS shelf in December 2008 and October 2010 (Fig. 1). Additional sampling information is provided in the Supplement.

After recording the sample volume, we passed the water through a column of $\mathrm{MnO}_{2}$ coated acrylic fiber (Mn fiber) via gravity with a flow rate less than $1 \mathrm{~L}$ per minute to quantitatively remove $\mathrm{Ra}$ (Moore, 1976, 2007). 

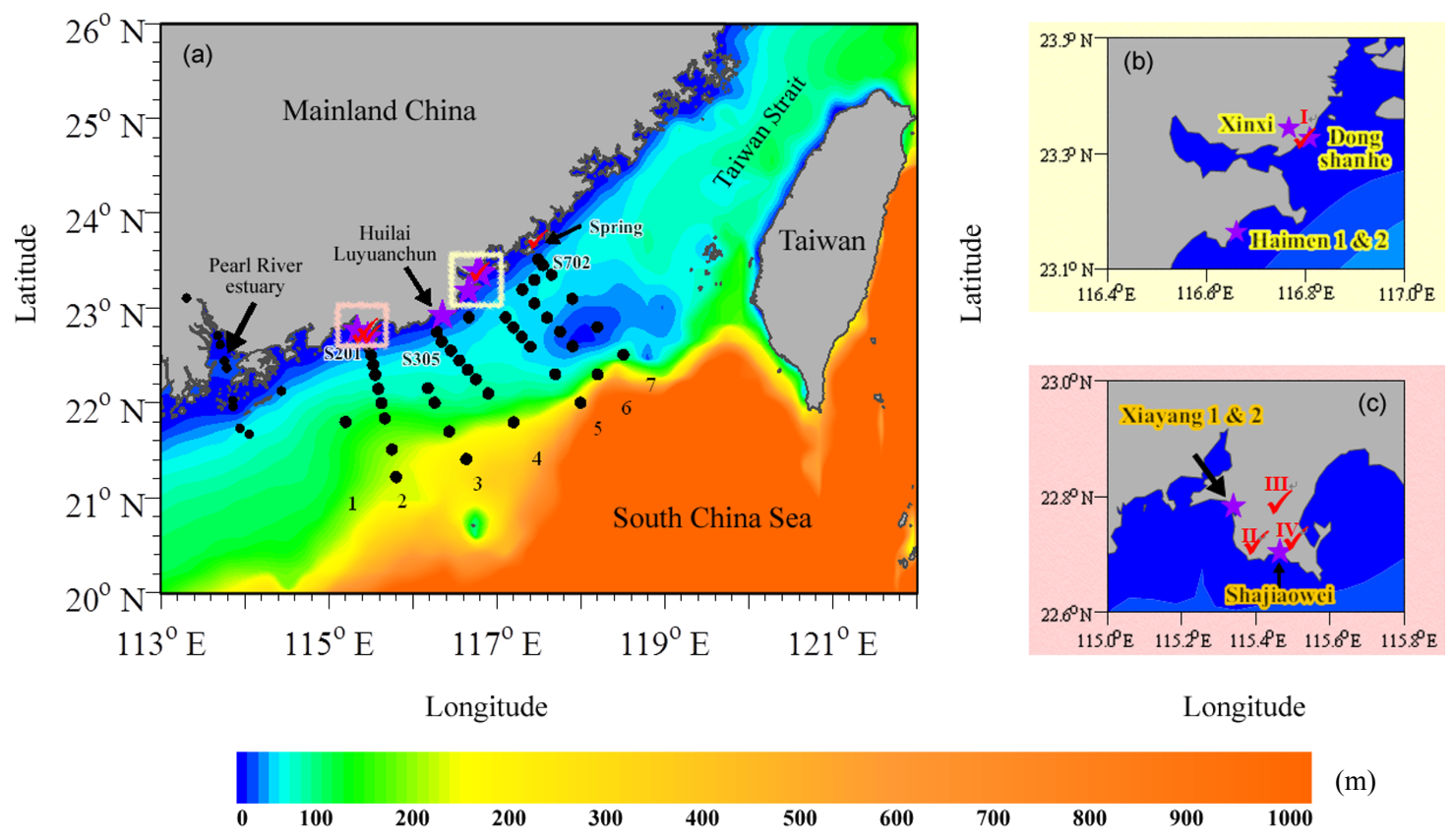

Fig. 1. Map of the northern South China Sea with isobaths showing the sampling sites (a) occupied during 30 June-8 July, 2008 and the sites for groundwater sampling along the coast (b and c). Black dots represent Ra samples in the surface water, the cross-shelf transects are marked by numbers $1-7$. Red check mark and purple star indicate locations of groundwater sampling in December 2008 and October 2010 , respectively.

\subsubsection{Measurements of short-lived and long-lived Ra isotopes}

In the laboratory, we washed Mn fiber samples with Ra free deionized water to remove the sea salts, flushed with compressed air for $\sim 7 \mathrm{~min}$ to adjust to an appropriate moisture content and then placed it in a Radium Delayed Coincidence Counter $(\mathrm{RaDeCC})$ system to determine the short-lived radium isotopes, ${ }^{223} \mathrm{Ra}\left(T_{1 / 2}=11.4\right.$ days $)$ and ${ }^{224} \mathrm{Ra}\left(T_{1 / 2}=3.7\right.$ days) (Moore and Arnold, 1996; Moore, 2008). This delayed coincidence system differentiates the alpha particle signals derived from ${ }^{219} \mathrm{Rn}$ and ${ }^{220} \mathrm{Rn}$, which are the decay daughters of ${ }^{223} \mathrm{Ra}$ and ${ }^{224} \mathrm{Ra}$, respectively (Giffin et al., 1963; Moore and Arnold, 1996). The associated uncertainties of the measurements were estimated according to Garcia-Solsona et al. (2008).

After the measurements of ${ }^{223} \mathrm{Ra}$ and ${ }^{224} \mathrm{Ra}$, we used two methods to determine long-lived $\mathrm{Ra}$ isotopes. One of the methods involved recounting the Mn fiber using the RaDeCC system in $\sim 6$ months after sample collection, which allowed for ingrowth of ${ }^{228} \mathrm{Th}$ from its precursor, ${ }^{228} \mathrm{Ra}\left(T_{1 / 2}=5.75\right.$ years). Upon correction for the decay of ${ }^{228} \mathrm{Th}$ that was originally coated on the Mn fiber from the initial samples, we obtained the ${ }^{228} \mathrm{Ra}$ activity as described in Moore et al. (2008). Our second approach to measure ${ }^{226} \mathrm{Ra}$ and ${ }^{228} \mathrm{Ra}$ was gamma counting. Except for the groundwater samples taken in 2010, our Mn fiber samples were leached with a mixture of $1 \mathrm{~mol} \mathrm{~L}^{-1}$ hydroxylamine hydrochloride and hydrogen peroxide solution at $50{ }^{\circ} \mathrm{C}$. Radium-228 and ${ }^{226} \mathrm{Ra}$ $\left(T_{1 / 2}=1600\right.$ years $)$ in the solution were co-precipitated with $\mathrm{BaSO}_{4}$ and the precipitate was sealed in a small counting vial for 3 weeks prior to the measurement with a well-type germanium detector (ORTEC, GWL-120-15-S). Radium-228 and ${ }^{226} \mathrm{Ra}$ were determined from their daughters ${ }^{228} \mathrm{Ac}$ (peaks at $911 \mathrm{keV}$ ) and ${ }^{214} \mathrm{~Pb}$ (peaks at 295 and $352 \mathrm{keV}$ ), respectively (Moore, 1984; Moore et al., 1985; Chen et al., 2010). The errors for the ${ }^{228} \mathrm{Ra}$ and ${ }^{226} \mathrm{Ra}$ measurements were in the range of $5-26 \%$ ( $1 \sigma$; based on counting statistics and standard propagation of errors).

\subsubsection{Measurements of major ions, carbonate system parameters, and inorganic nutrients}

Samples for sodium, magnesium, and calcium analyses were filtered through a $0.45 \mu \mathrm{m}$ membrane filter and refrigerated. They were then analyzed on a Dionex ICS-2500 ion chromatograph. The detailed description of sampling and measurements of inorganic carbon and nutrients in this cruise were presented in Cao et al. (2011) and Han et al. (2012), respectively. These chemical parameters in groundwater samples were measured using the same methods as those for the estuary and shelf waters. 


\section{Results}

\subsection{Hydrography and hydrochemistry in the NSCS}

The basic hydrological information during this cruise was reported in Shu et al. (2011a, b) and Gan et al. (2009a, b). In brief, there was continuous rainfall ten days prior to our cruise in the drainage basin of the Pearl River, resulting in nearly doubled water discharge as compared to the long term average in the wet season (Cao et al., 2011). The abundant river discharge clearly resulted in a large plume spreading eastward over the shelf as seen from the salinity distribution (Fig. 2b). A minimum salinity of 26.6 was measured at Site S105 about $70 \mathrm{~km}$ away from the mouth of the PRE. This plume water also appeared at $\sim 350 \mathrm{~km}$ towards the Taiwan Shoal over the NSCS shelf, with warm temperatures (27.2$30.2^{\circ} \mathrm{C}$ ) (Fig. 2a) and low salinities (26.6-33.3) (Fig. 2b), indicating eastward spreading driven by the southwestern monsoon. We observed that the shelf regions laced with these plume waters were characterized by low DIC (Cao et al., 2011) but high inorganic nitrogen $\left(\mathrm{NO}_{3}^{-}+\mathrm{NO}_{2}^{-}\right)$and relatively low $\mathrm{PO}_{4}$ and $\mathrm{Si}$ (Han et al., 2012), indicating that DIC was reduced by the enhanced biological consumption caused by the high nutrients supplied from the Pearl River plume.

In addition to the plume, the study area is characterized by coastal upwelling as demonstrated by the relatively high salinity (averaging 33.8) and low temperature (averaging $23.7^{\circ} \mathrm{C}$ ) at the inner shelf stations from Transects 4 to 7 (Fig. 2a and b) (Gan et al., 2010; Shu et al., 2011a). Not surprisingly, the upwelled water was enriched in DIC, TAlk (Cao et al., 2011), and nutrients (Han et al., 2012). Note that the apparent distribution pattern of nutrients and the carbonate system parameters reflects an interplay of the upwelled water mixed with nearshore surface water and biological consumption. While the plume is entrained and transported by the upwelled water, its buoyancy modulates the circulation over the shelf. The cross sections of temperature and salinity along Transect 2 demonstrated that the bottom cold water $\left(19.2-21.3^{\circ} \mathrm{C}\right)$ encroached onto the shelf from the slope at $\sim 100 \mathrm{~m}$ but it did not outcrop at the surface due to the stratification induced by the low salinity (25.7-33.3) Pearl River plume (Fig. 3).

\subsection{Ra distributions on the NSCS shelf}

\subsubsection{Surface distributions of Ra isotopes on the NSCS shelf}

Surface Ra activity showed considerable spatial variations in the study area (Table 1 and Fig. $2 \mathrm{c}$ to f). Radium$228,{ }^{226} \mathrm{Ra},{ }^{223} \mathrm{Ra}$, and excess ${ }^{224} \mathrm{Ra}$ ranged from 6.85 to 61.2 , 5.15 to $27.9,0.02$ to 1.94 , and 0.09 to $44.0 \mathrm{dpm} 100 \mathrm{~L}^{-1}$, respectively. One unique feature of ${ }^{228} \mathrm{Ra}$ distribution in the NSCS compared with other shelf areas (e.g. Moore, 2000b) is an increase in activity with distance offshore. This can be attributed to the eastward dispersal of the high-radium river plume offshore relative to the coastal upwelling nearshore. Figure 2e showed relatively low ${ }^{228} \mathrm{Ra}$ activity on the inner shelf (longitude and latitude ranged from 116.7 to $117.7^{\circ} \mathrm{E}$, from 22.9 to $23.5^{\circ} \mathrm{N}$ ) in the range of 12.4 to $29.2 \mathrm{dpm}$ $100 \mathrm{~L}^{-1}$, which is mainly controlled by coastal upwelling, suggesting that bottom/subsurface water with low ${ }^{228} \mathrm{Ra}$ activity outcropped to the surface. In contrast, there were higher ${ }^{228} \mathrm{Ra}$ activities in the Pearl River plume zone, which matched with the lower salinity (Fig. 2b). The highest ${ }^{228} \mathrm{Ra}$ of $61.2 \mathrm{dpm} 100 \mathrm{~L}^{-1}$ appeared at the station (S106) closest to the Pearl River's mouth, corresponding to the low salinity center of the plume (Fig. 2b). Radium-226 in the surface water of the NSCS followed the same pattern (Fig. 2f), suggesting its distribution is controlled by the same sources and transport processes.

The distribution of ex ${ }^{224} \mathrm{Ra}$ (excess ${ }^{224} \mathrm{Ra}$, corrected for the ingrowth from ${ }^{228} \mathrm{Th}$ ) (Fig. 2d) was significantly different from those of long-lived Ra isotopes $\left({ }^{226} \mathrm{Ra}\right.$ and $\left.{ }^{228} \mathrm{Ra}\right)$. The presence of the highest ex ${ }^{224} \mathrm{Ra}$ in the coastal upwelling region suggests a potential subsurface source for this isotope. In contrast, ex ${ }^{224} \mathrm{Ra}$ in the Pearl River plume was not so apparent (except at S106), likely because the half-life of ${ }^{224} \mathrm{Ra}$ $\left(T_{1 / 2}=3.7\right.$ days $)$ is too short to trace the Pearl River plume farther off the estuary. Radium-223 (Fig. 2c) was relatively high in the Pearl River plume, ranging from 0.72 to $1.91 \mathrm{dpm}$ $100 \mathrm{~L}^{-1}$, a likely result of its longer half life $\left(T_{1 / 2}=11.4\right.$ days). Like ex ${ }^{224} \mathrm{Ra}$, high ${ }^{223} \mathrm{Ra}\left(0.72\right.$ to $\left.1.51 \mathrm{dpm} 100 \mathrm{~L}^{-1}\right)$ existed in the nearshore coastal upwelling zone (Fig. 2c). However, it was hard to differentiate the ${ }^{223} \mathrm{Ra}$ from the river plume and from coastal upwelling since the ${ }^{223} \mathrm{Ra}$ activity was similar in these two zones (Fig. 2c).

\subsubsection{Vertical distributions of Ra isotopes on the NSCS shelf}

To verify the impact of subsurface/bottom water on the distributions of $\mathrm{Ra}$ isotopes in surface waters, we sampled the water column at stations S201, S702 and S305 (Fig. 1). Figure 4a shows ${ }^{226} \mathrm{Ra}$ and ${ }^{228} \mathrm{Ra}$ activities at Site S201 decreased with depth while ex ${ }^{224} \mathrm{Ra}$ and ${ }^{223} \mathrm{Ra}$ activities increased with depth. These distributions provide strong evidence that upwelling would elevate ex ${ }^{224} \mathrm{Ra}$ and ${ }^{223} \mathrm{Ra}$ but lower ${ }^{228} \mathrm{Ra}$ and ${ }^{226} \mathrm{Ra}$ activities in surface waters.

To further provide a composite view of which isotopes tracked what individual processes, we plotted temperature and salinity with the data of various Ra isotopes superimposed on the plot (Fig. 5). Again, short-lived Ra isotopes (ex ${ }^{224} \mathrm{Ra}$ and ${ }^{223} \mathrm{Ra}$ ) were enhanced in both the subsurface water and river plume, but were reduced in the surface seawater. In contrast, long-lived $\mathrm{Ra}$ isotopes $\left({ }^{228} \mathrm{Ra}\right.$ and $\left.{ }^{226} \mathrm{Ra}\right)$ were enriched in the river plume area, but were low in both the surface SCS seawater and subsurface water/upwelling zone. Thus, $\mathrm{Ra}$ isotopes will be applied to assess the transport rate 

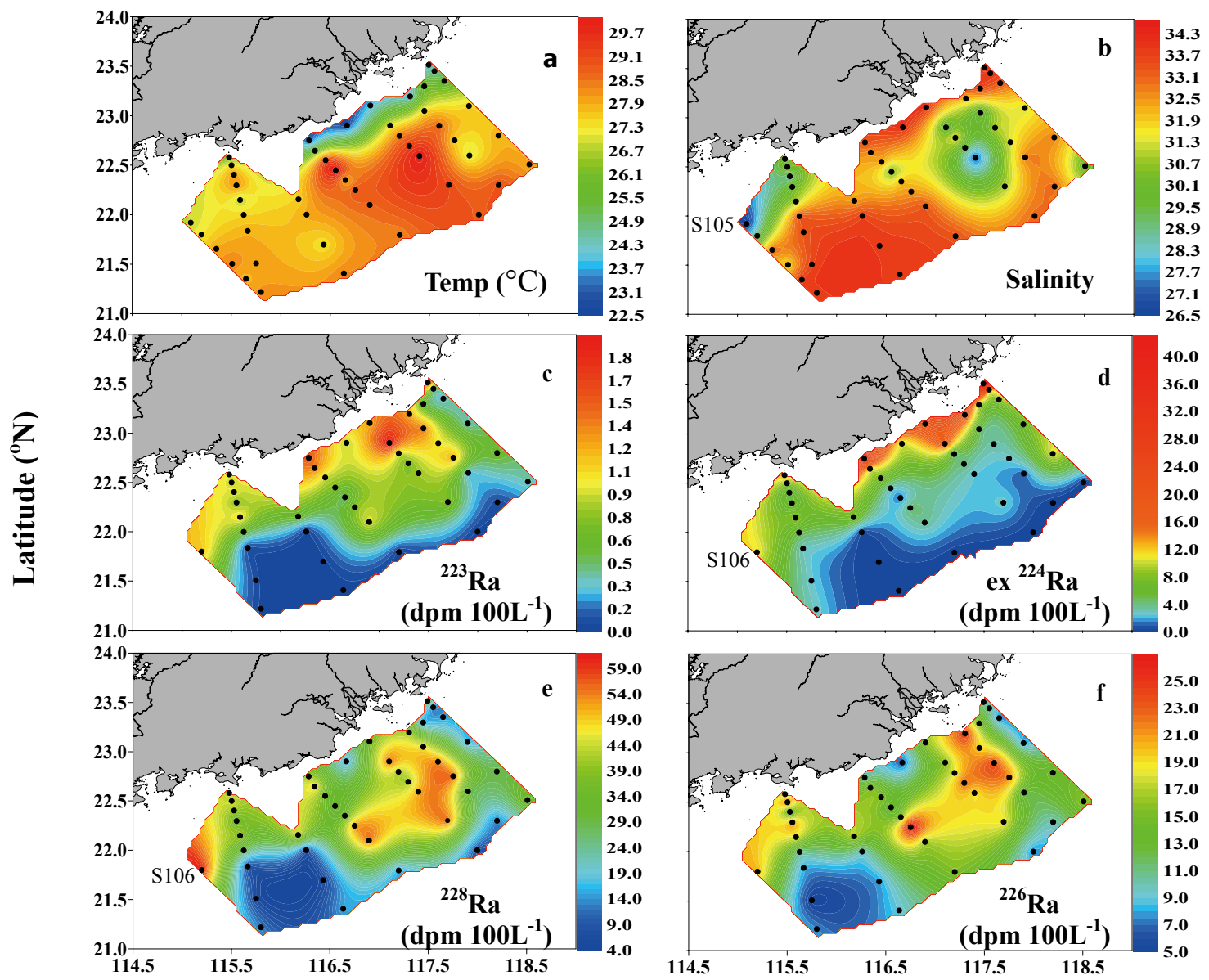

\section{Longitude $\left({ }^{0} \mathbf{E}\right)$}

Fig. 2. Contour maps showing the distributions of (a) temperature $\left({ }^{\circ} \mathrm{C}\right)$, (b) salinity, (c) ${ }^{223} \mathrm{Ra}\left(\mathrm{dpm} 100 \mathrm{~L}^{-1}\right.$ ), (d) ex ${ }^{224} \mathrm{Ra}$ (excess ${ }^{224} \mathrm{Ra}$, corrected for the ingrowth from ${ }^{228} \mathrm{Th}$; dpm $\left.100 \mathrm{~L}^{-1}\right)$, (e) ${ }^{228} \mathrm{Ra}\left(\mathrm{dpm} 100 \mathrm{~L}^{-1}\right)$, and (f) ${ }^{226} \mathrm{Ra}\left(\mathrm{dpm} 100 \mathrm{~L}^{-1}\right)$ on the northern South China Sea shelf during 30 June-8 July, 2008.
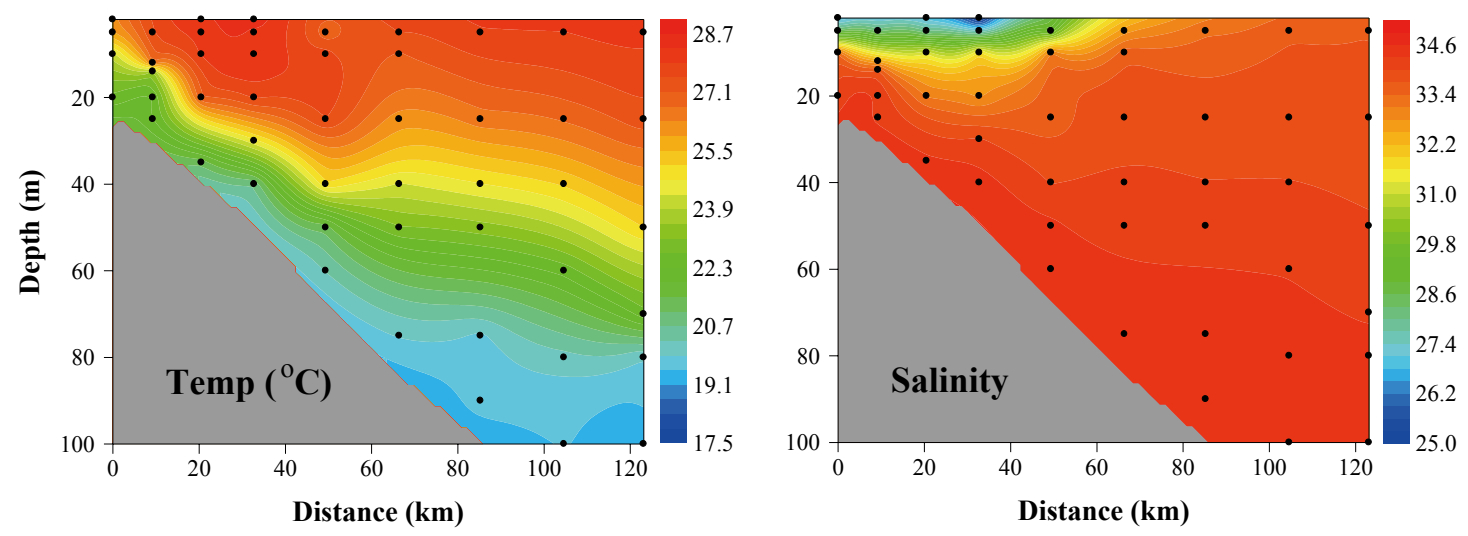

Fig. 3. Temperature $\left({ }^{\circ} \mathrm{C}\right)$ and salinity at the cross-shelf transect 2 on the northern South China Sea shelf. 
Table 1. Activities of Ra isotopes at the sampling sites ${ }^{\#}$ on the northern South China Sea shelf and in the Pearl River estuary.

\begin{tabular}{|c|c|c|c|c|c|c|c|}
\hline Sample & Latitude & Longitude & \multirow{2}{*}{ Salinity } & $\mathbf{e x}^{224} \mathbf{R a}^{*}$ & ${ }^{223} \mathbf{R a}$ & ${ }^{226} \mathbf{R a}$ & ${ }^{228} \mathbf{R a}$ \\
\hline ID & $\left({ }^{\circ} \mathbf{N}\right)$ & $\left({ }^{\circ} \mathbf{E}\right)$ & & \multicolumn{4}{|c|}{$(\mathrm{dpm} 100 \mathrm{~L})^{-1}$} \\
\hline \multicolumn{8}{|c|}{ Northern South China Sea } \\
\hline S105 & 21.92 & 115.09 & 26.6 & - & - & - & - \\
\hline S106 & 21.80 & 115.20 & 29.1 & $11.39 \pm 0.52$ & $1.13 \pm 0.11$ & $20.18 \pm 1.23$ & $55.55 \pm 2.50$ \\
\hline S107 & 21.65 & 115.35 & 32.9 & - & - & - & - \\
\hline S108 & 21.50 & 115.51 & 31.6 & - & - & - & - \\
\hline S109 & 21.35 & 115.65 & 33.8 & - & - & - & - \\
\hline S110 & 21.22 & 115.80 & 33.8 & $2.86 \pm 0.16$ & $0.03 \pm 0.02$ & $7.59 \pm 0.49$ & $12.74 \pm 1.39$ \\
\hline S209 & 21.51 & 115.75 & 33.7 & $2.62 \pm 0.15$ & $0.07 \pm 0.02$ & $5.15 \pm 0.80$ & $7.10 \pm 0.91$ \\
\hline S207 & 21.84 & 115.67 & 33.3 & $2.92 \pm 0.19$ & $0.06 \pm 0.02$ & $8.22 \pm 0.87$ & $7.96 \pm 1.46$ \\
\hline S206 & 22.00 & 115.63 & 33.4 & $5.11 \pm 0.31$ & $0.53 \pm 0.06$ & $10.46 \pm 1.45$ & $28.17 \pm 3.36$ \\
\hline S205 & 22.15 & 115.59 & 30.8 & $8.61 \pm 0.38$ & $1.05 \pm 0.09$ & $18.40 \pm 2.22$ & $40.20 \pm 3.31$ \\
\hline S204 & 22.30 & 115.55 & 30.1 & $5.09 \pm 0.32$ & $0.73 \pm 0.07$ & $20.95 \pm 1.62$ & $35.00 \pm 4.55$ \\
\hline S203 & 22.40 & 115.53 & 28.5 & $5.25 \pm 0.31$ & $0.97 \pm 0.08$ & $12.66 \pm 1.54$ & $40.31 \pm 2.61$ \\
\hline S202 & 22.50 & 115.50 & 30.8 & $8.17 \pm 0.37$ & $0.91 \pm 0.08$ & $22.84 \pm 2.90$ & $45.10 \pm 4.67$ \\
\hline S201 & 22.58 & 115.48 & 29.6 & $13.26 \pm 0.51$ & $0.96 \pm 0.12$ & $16.49 \pm 1.60$ & $41.25 \pm 2.48$ \\
\hline $\mathrm{S} 201-7 \mathrm{~m}$ & 22.58 & 115.48 & 32.1 & $17.63 \pm 0.95$ & $1.38 \pm 0.18$ & $11.41 \pm 0.75$ & $35.59 \pm 3.26$ \\
\hline S201-15 m & 22.58 & 115.48 & 34.1 & $25.94 \pm 0.87$ & $1.69 \pm 0.21$ & $8.27 \pm 0.78$ & $27.94 \pm 2.72$ \\
\hline S305 & 22.16 & 116.18 & 32.4 & $7.56 \pm 0.42$ & $0.59 \pm 0.08$ & $11.41 \pm 0.75$ & $35.59 \pm 3.26$ \\
\hline $\mathrm{S} 305-10 \mathrm{~m}$ & 22.16 & 116.18 & 33.0 & $0.27 \pm 0.16$ & $0.12 \pm 0.03$ & $7.61 \pm 0.87$ & $14.39 \pm 1.44$ \\
\hline $\mathrm{S} 305-25 \mathrm{~m}$ & 22.16 & 116.18 & 33.8 & $0.22 \pm 0.12$ & $0.05 \pm 0.02$ & $5.19 \pm 0.72$ & $7.68 \pm 1.21$ \\
\hline $\mathrm{S} 305-45 \mathrm{~m}$ & 22.16 & 116.18 & 34.1 & $1.78 \pm 0.20$ & $0.02 \pm 0.02$ & $8.08 \pm 0.91$ & $5.13 \pm 2.50$ \\
\hline $\mathrm{S} 305-60 \mathrm{~m}$ & 22.16 & 116.18 & 34.4 & $5.06 \pm 0.29$ & $0.22 \pm 0.04$ & $8.93 \pm 1.96$ & $10.2 \pm 3.96$ \\
\hline S306 & 22.00 & 116.26 & 33.7 & $0.25 \pm 0.14$ & $0.03 \pm 0.02$ & $9.37 \pm 1.46$ & $7.43 \pm 3.12$ \\
\hline S308 & 21.70 & 116.43 & 33.8 & $0.31 \pm 0.15$ & $0.03 \pm 0.03$ & $7.87 \pm 0.67$ & $6.85 \pm 1.21$ \\
\hline S310 & 21.41 & 116.64 & 33.8 & $0.01 \pm 0.14$ & $0.02 \pm 0.01$ & $9.11 \pm 0.82$ & $15.30 \pm 1.50$ \\
\hline S409 & 21.80 & 117.20 & 33.4 & $0.09 \pm 0.11$ & $0.03 \pm 0.02$ & $15.36 \pm 1.89$ & $16.00 \pm 2.08$ \\
\hline S407 & 22.10 & 116.90 & 33.3 & $3.76 \pm 0.26$ & $0.94 \pm 0.09$ & $16.33 \pm 0.84$ & $54.62 \pm 2.40$ \\
\hline S406 & 22.25 & 116.75 & 32.4 & $4.51 \pm 0.34$ & $0.74 \pm 0.08$ & $27.88 \pm 2.30$ & $52.66 \pm 3.16$ \\
\hline S405 & 22.35 & 116.65 & 32.0 & $1.24 \pm 0.19$ & $0.42 \pm 0.05$ & $15.14 \pm 1.26$ & $33.62 \pm 2.38$ \\
\hline S404 & 22.45 & 116.55 & 30.4 & $2.93 \pm 0.29$ & $0.72 \pm 0.08$ & $12.75 \pm 1.65$ & $31.08 \pm 4.34$ \\
\hline S403 & 22.55 & 116.45 & 32.4 & $7.81 \pm 0.43$ & $0.89 \pm 0.09$ & $15.72 \pm 1.46$ & $34.64 \pm 3.38$ \\
\hline S402 & 22.65 & 116.34 & 32.6 & $10.31 \pm 0.51$ & $1.37 \pm 0.11$ & $15.66 \pm 3.84$ & $48.08 \pm 5.35$ \\
\hline S401 & 22.75 & 116.29 & 33.4 & $29.15 \pm 1.11$ & $1.51 \pm 0.16$ & $10.14 \pm 1.52$ & $40.06 \pm 4.18$ \\
\hline S401-b & 22.90 & 116.67 & 34.0 & $10.21 \pm 0.46$ & $0.86 \pm 0.10$ & $6.57 \pm 0.66$ & $16.70 \pm 1.82$ \\
\hline S501 & 23.10 & 116.90 & 33.9 & $19.01 \pm 0.61$ & $1.21 \pm 0.12$ & $16.02 \pm 0.99$ & - \\
\hline S503 & 22.90 & 117.10 & 29.5 & $17.21 \pm 0.42$ & $1.94 \pm 0.15$ & $15.79 \pm 1.01$ & $55.31 \pm 2.73$ \\
\hline S504 & 22.80 & 117.20 & 31.6 & $4.35 \pm 0.31$ & $0.88 \pm 0.10$ & $18.11 \pm 2.55$ & $42.07 \pm 4.37$ \\
\hline S505 & 22.69 & 117.30 & 29.4 & $4.35 \pm 0.31$ & $0.72 \pm 0.08$ & $22.49 \pm 2.47$ & $41.41 \pm 5.16$ \\
\hline S506 & 22.59 & 117.40 & 27.1 & $2.56 \pm 0.27$ & $0.80 \pm 0.08$ & $18.74 \pm 1.44$ & $51.49 \pm 2.61$ \\
\hline S508 & 22.30 & 117.70 & 30.9 & $2.87 \pm 0.27$ & $0.71 \pm 0.09$ & $18.70 \pm 2.18$ & $55.38 \pm 4.07$ \\
\hline
\end{tabular}

of the Pearl River plume and the coastal upwelling during our sampling period (See Sect. 4.1).

\subsection{Surface distributions of Ra isotopes in the Pearl River estuary}

The radium versus salinity plots (Fig. 6) revealed that all of the four $\mathrm{Ra}$ isotopes were distributed coherently in surface waters of the PRE, i.e. with low activities at zero salinity, followed by an increase with salinity until reaching the highest activities at salinities of 2.5-9.0. Ra activities decreased then toward the lowest values in high salinity seawater. Such a pattern has been observed in estuaries of other large rivers, such as the Chao Phraya River and the Mississippi River and may reflect release of $\mathrm{Ra}$ isotopes from particles into solution upon estuarine mixing (Krest et al., 1999; Moore and Krest, 2004; Dulaiova and Burnett, 2006). 
Table 1. Continued.

\begin{tabular}{|c|c|c|c|c|c|c|c|}
\hline \multirow{2}{*}{$\begin{array}{l}\text { Sample } \\
\text { ID }\end{array}$} & \multirow{2}{*}{$\begin{array}{l}\text { Latitude } \\
\left({ }^{\circ} \mathrm{N}\right)\end{array}$} & \multirow{2}{*}{$\begin{array}{l}\text { Longitude } \\
\left({ }^{\circ} \mathbf{E}\right)\end{array}$} & \multirow{2}{*}{ Salinity } & $\mathbf{e x}^{224} \mathbf{R a}^{*}$ & ${ }^{223} \mathbf{R a}$ & ${ }^{226} \mathbf{R a}$ & ${ }^{228} \mathbf{R a}$ \\
\hline & & & & \multicolumn{4}{|c|}{$(\operatorname{dpm} 100 \mathrm{~L})^{-1}$} \\
\hline S605 & 22.75 & 117.75 & 31.3 & $2.78 \pm 0.28$ & $1.19 \pm 0.09$ & $21.69 \pm 2.55$ & $55.67 \pm 5.41$ \\
\hline S604 & 22.90 & 117.60 & 31.0 & $3.52 \pm 0.31$ & $0.99 \pm 0.09$ & $24.05 \pm 2.62$ & $53.69 \pm 5.08$ \\
\hline S603 & 23.05 & 117.45 & 29.4 & $4.84 \pm 0.27$ & $1.38 \pm 0.10$ & $19.21 \pm 1.93$ & $47.31 \pm 3.32$ \\
\hline S602 & 23.20 & 117.30 & 32.2 & $18.71 \pm 0.28$ & $1.22 \pm 0.15$ & $24.89 \pm 3.37$ & $41.15 \pm 3.43$ \\
\hline S601 & 23.30 & 117.45 & 33.6 & $9.46 \pm 0.29$ & $0.49 \pm 0.05$ & $15.08 \pm 1.85$ & $15.76 \pm 1.89$ \\
\hline S701 & 23.51 & 117.49 & 33.8 & $43.99 \pm 0.94$ & $1.70 \pm 0.19$ & $9.98 \pm 1.53$ & $29.15 \pm 2.45$ \\
\hline S702 & 23.45 & 117.55 & 33.9 & $11.19 \pm 0.46$ & $0.40 \pm 0.07$ & $10.76 \pm 1.60$ & $12.38 \pm 2.91$ \\
\hline S702-15 m & 23.45 & 117.55 & 33.9 & $6.77 \pm 0.37$ & $0.25 \pm 0.06$ & $8.14 \pm 1.47$ & $16.67 \pm 1.73$ \\
\hline S702-35 m & 23.45 & 117.55 & 33.9 & $9.89 \pm 0.49$ & $0.30 \pm 0.08$ & $10.65 \pm 1.09$ & $16.05 \pm 2.16$ \\
\hline S703 & 23.35 & 117.65 & 33.3 & $8.88 \pm 0.69$ & $0.32 \pm 0.10$ & $7.79 \pm 0.90$ & $14.92 \pm 1.95$ \\
\hline S705 & 23.10 & 117.90 & 31.3 & $7.01 \pm 0.65$ & $0.35 \pm 0.09$ & $8.13 \pm 1.46$ & $16.66 \pm 1.72$ \\
\hline S707 & 22.80 & 118.20 & 32.6 & $10.85 \pm 0.34$ & $0.57 \pm 0.06$ & $14.40 \pm 1.39$ & $28.75 \pm 1.98$ \\
\hline S709 & 22.51 & 118.51 & 29.9 & $0.19 \pm 0.16$ & $0.35 \pm 0.03$ & $15.94 \pm 1.71$ & $34.96 \pm 2.15$ \\
\hline \multicolumn{8}{|c|}{ Pearl River estuary } \\
\hline A & 21.67 & 114.05 & 28.7 & $4.53 \pm 0.54$ & $0.43 \pm 0.11$ & $14.80 \pm 0.85$ & $35.85 \pm 2.78$ \\
\hline B & 21.73 & 113.94 & 22.8 & $7.60 \pm 0.92$ & $0.84 \pm 0.60$ & $20.44 \pm 1.28$ & $57.07 \pm 4.93$ \\
\hline $\mathrm{C}$ & 21.96 & 113.86 & 14.5 & $22.77 \pm 1.61$ & $1.73 \pm 0.81$ & $22.76 \pm 1.69$ & $70.62 \pm 4.32$ \\
\hline $\mathrm{D}$ & 22.03 & 113.86 & 8.7 & $34.57 \pm 1.77$ & $2.35 \pm 0.88$ & $29.83 \pm 1.58$ & $75.23 \pm 4.66$ \\
\hline $\mathrm{E}$ & 22.37 & 113.78 & 6.2 & $51.14 \pm 2.51$ & $2.56 \pm 1.09$ & $19.67 \pm 2.11$ & $60.82 \pm 6.83$ \\
\hline $\mathrm{F}$ & 22.44 & 113.76 & 2.6 & $63.31 \pm 4.27$ & $1.35 \pm 0.82$ & $30.74 \pm 1.66$ & $66.19 \pm 3.37$ \\
\hline $\mathrm{G}$ & 22.61 & 113.71 & 1.0 & $39.42 \pm 1.35$ & $0.80 \pm 0.74$ & $23.76 \pm 2.12$ & $48.08 \pm 4.97$ \\
\hline $\mathrm{H}$ & 22.71 & 113.68 & 0.4 & $32.32 \pm 1.87$ & $0.87 \pm 0.88$ & $14.97 \pm 1.44$ & $35.36 \pm 3.70$ \\
\hline I & 23.11 & 113.31 & 0.0 & $31.80 \pm 1.94$ & $1.38 \pm 0.59$ & $23.60 \pm 2.05$ & $27.59 \pm 7.15$ \\
\hline
\end{tabular}

*ex ${ }^{224} \mathrm{Ra}$ denotes excess ${ }^{224} \mathrm{Ra}$, corrected for the ingrowth from ${ }^{228} \mathrm{Th}$.

\# Water column samples for Ra isotopes were collected at stations S201, S305 and S702 and only surface water was collected at the rest of the stations.
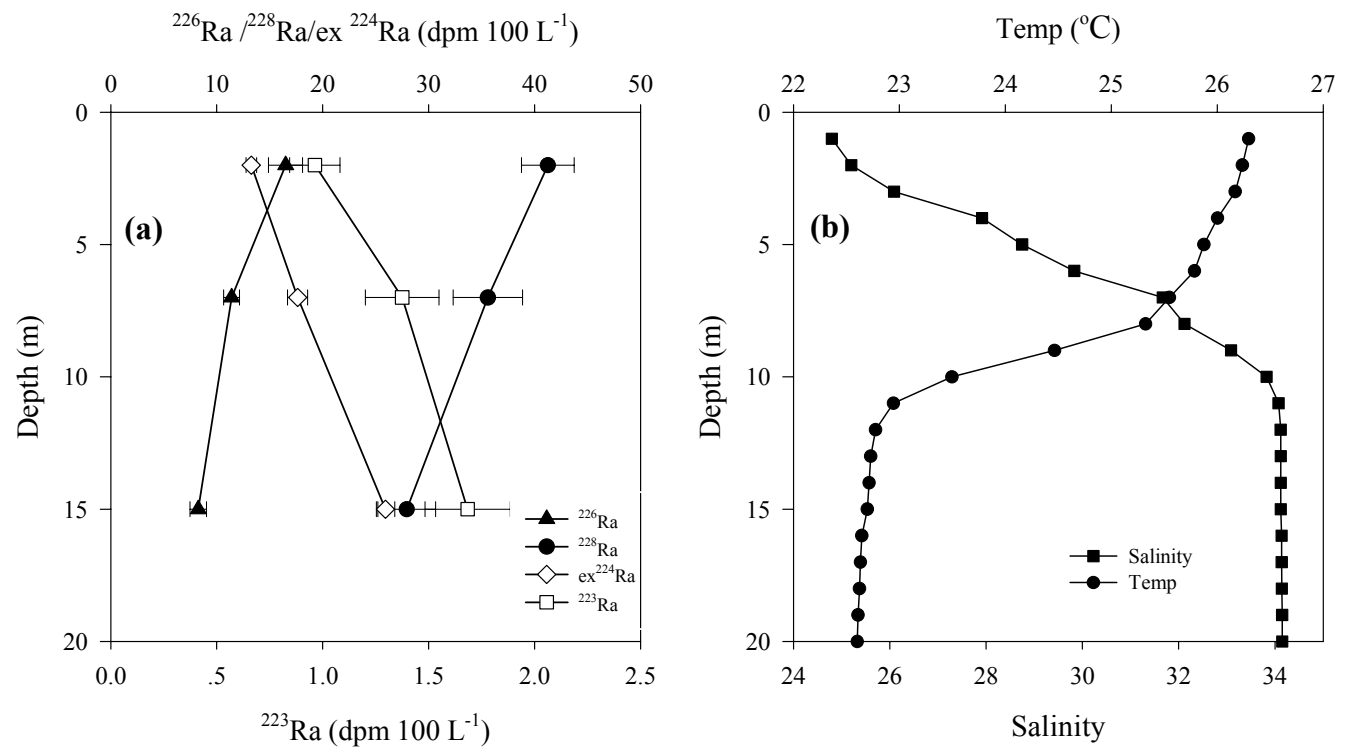

Fig. 4. Vertical profiles of ${ }^{226} \mathrm{Ra},{ }^{228} \mathrm{Ra}$, ex ${ }^{224} \mathrm{Ra}$ (excess ${ }^{224} \mathrm{Ra}$, corrected for the ingrowth from ${ }^{228} \mathrm{Th}$ ), and ${ }^{223} \mathrm{Ra}(\mathbf{a})$ and temperature and salinity (b) at S201 located nearest to the shore on Transect 2. 

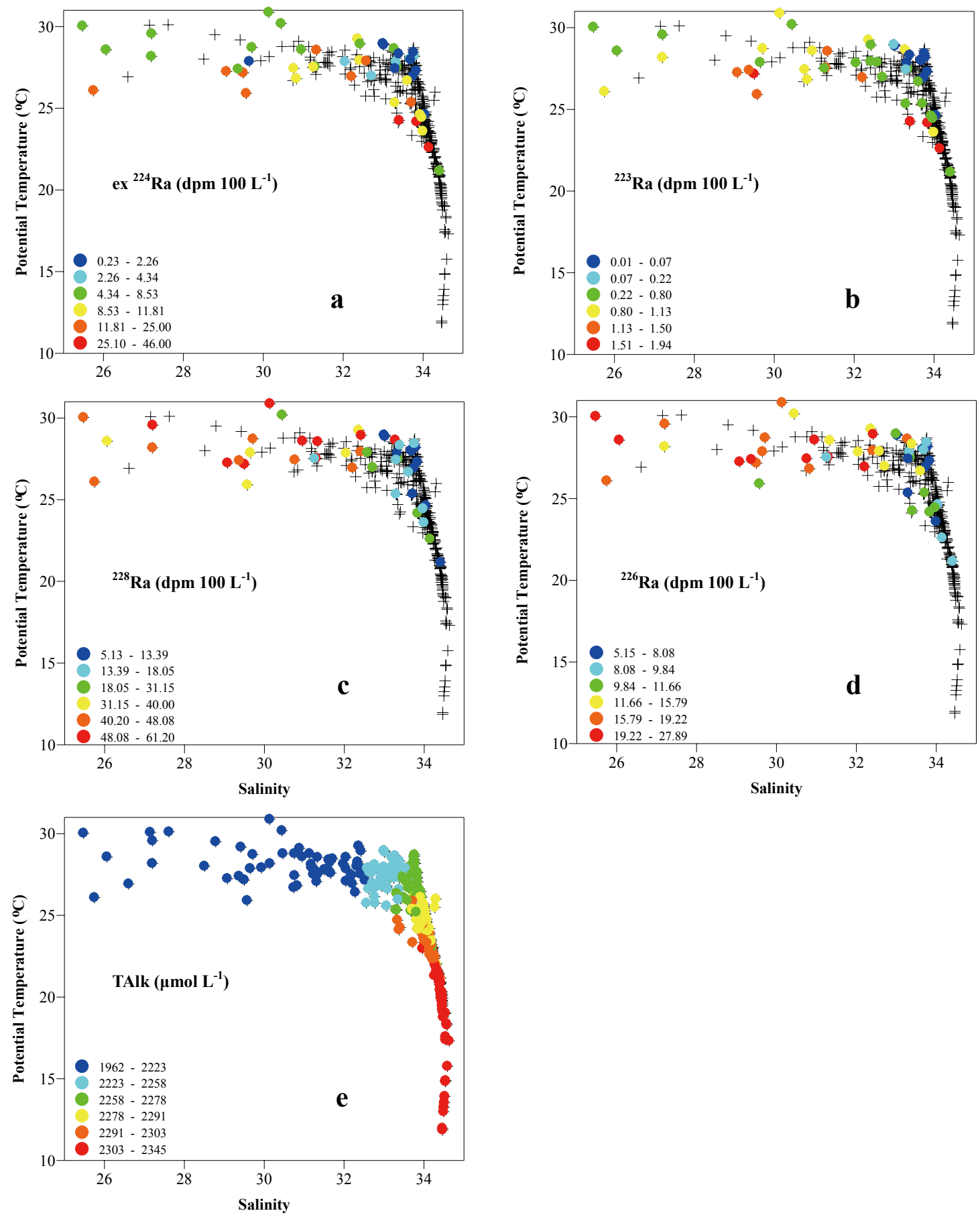

Fig. 5. Temperature-salinity diagrams superimposed with the data of (a) ex ${ }^{224} \mathrm{Ra}$ (excess ${ }^{224} \mathrm{Ra}$, corrected for the ingrowth from ${ }^{228} \mathrm{Th}$ ), (b) ${ }^{223} \mathrm{Ra}$, (c) ${ }^{228} \mathrm{Ra}$, (d) ${ }^{226} \mathrm{Ra}$, (e) TAlk (total alkalinity). Crosses represent the temperature and salinity data. Circles are the Ra quartet and TAlk data for samples collected on the northern South China Sea shelf during 30 June-8 July, 2008.

\subsection{Ra isotopes and other dissolved constituents in the NSCS groundwater}

We sampled freshwater supply-wells (salinity near nil) and one saline spring (salinity was 7.2) along the shoreline in 2008 (Table S1 in the Supplement). In 2010, we collected both fresh (salinity: 0-0.5) and brackish groundwater (salinity: 8.5-24.3) as pore water within the beach sediments along the NSCS shelf (Table S1 in the Supplement). Briefly, $\mathrm{Ra}$ activities were enriched in all of the 

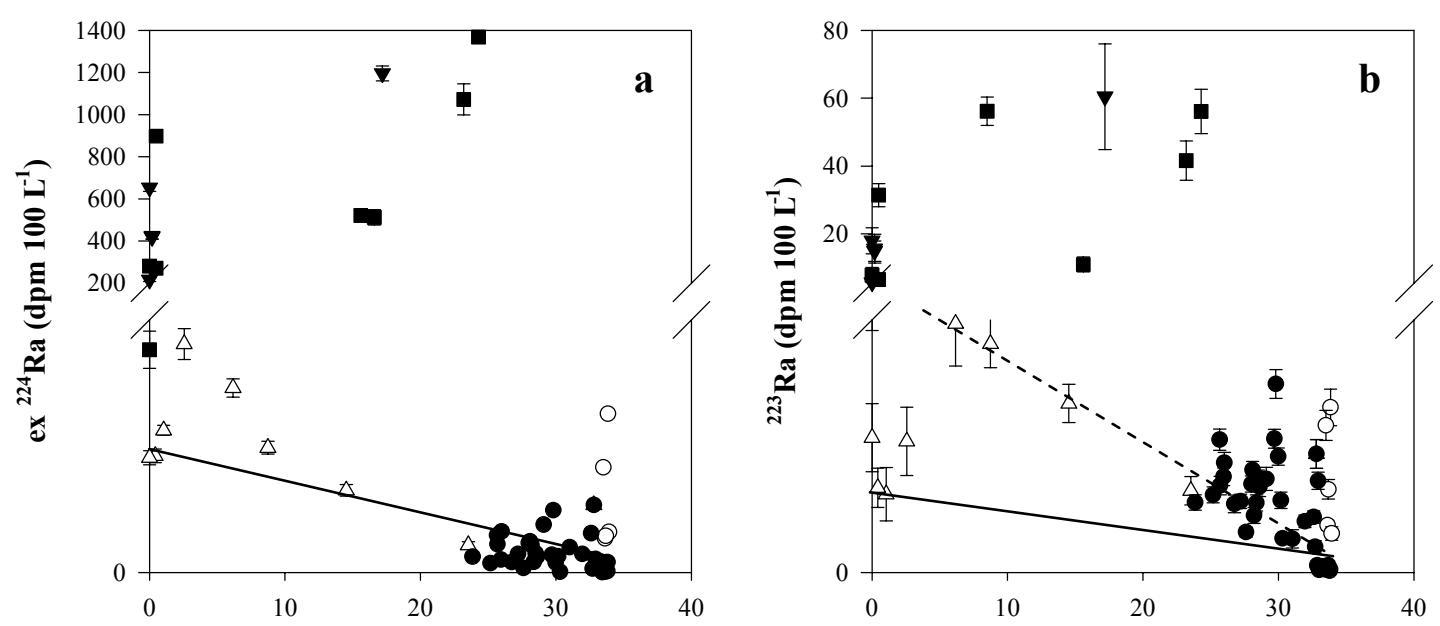

$\triangle \quad$ Pearl River estuary

O Upwelling

- NSCS shelf water

- Subteranean Estuary-2008

- Subteranean Estuary-2010
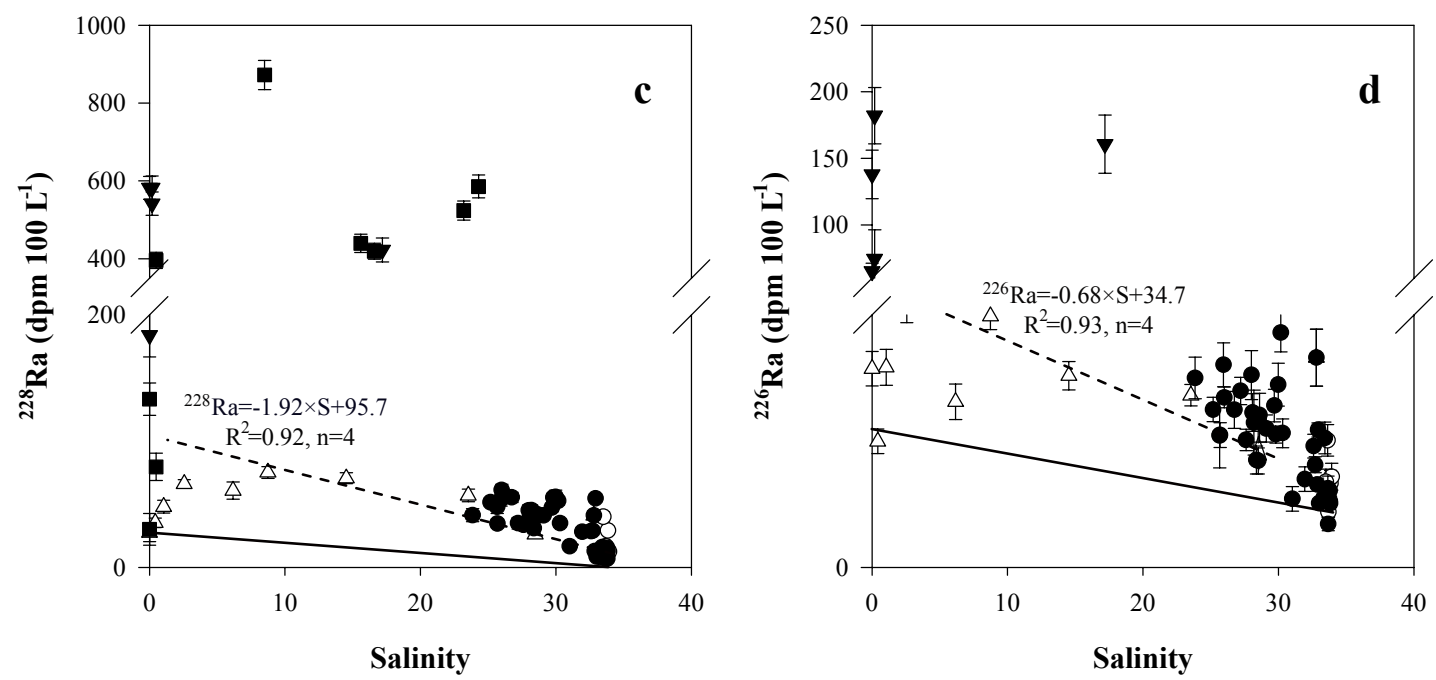

Fig. 6. Plots of (a) ex ${ }^{224} \mathrm{Ra}$ (excess ${ }^{224} \mathrm{Ra}$, corrected for the ingrowth from ${ }^{228} \mathrm{Th}$ ), (b) ${ }^{223} \mathrm{Ra}$, (c) ${ }^{228} \mathrm{Ra}$, and (d) ${ }^{226} \mathrm{Ra}$ versus salinity in the Pearl River estuary, northern South China Sea (NSCS) shelf waters and NSCS subterranean estuary. Solid lines represent the conservative mixing line between the freshwater end-member of the Pearl River and offshore surface seawater. Dotted lines denote conservative mixing after the Ra peak with salinity $>9$ in the Pearl River estuary. The linear regression equations shown in panels $\mathrm{c}$ and $\mathrm{d}$ are based on the ${ }^{228} \mathrm{Ra}$ and ${ }^{226} \mathrm{Ra}$ vs salinity plots at salinity $>9$.

groundwater samples with an average of $25.0 \pm 1.45 \mathrm{dpm}$ $100 \mathrm{~L}^{-1}$ for ${ }^{223} \mathrm{Ra}, 686 \pm 7.12 \mathrm{dpm} 100 \mathrm{~L}^{-1}$ for ex ${ }^{224} \mathrm{Ra}$, $124 \pm 8.45 \mathrm{dpm} 100 \mathrm{~L}^{-1}$ for ${ }^{226} \mathrm{Ra}$, and $413 \pm 10.2 \mathrm{dpm}$ $100 \mathrm{~L}^{-1}$ for ${ }^{228} \mathrm{Ra}$; all of which were higher relative to

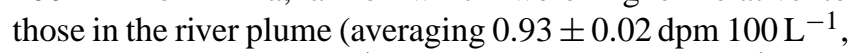
$6.25 \pm 0.09 \mathrm{dpm} 100 \mathrm{~L}^{-1}, 18.2 \pm 0.81 \mathrm{dpm} 100 \mathrm{~L}^{-1}$, and $41.6 \pm 0.10 \mathrm{dpm} 100 \mathrm{~L}^{-1}$, respectively) and offshore (averaging $0.07 \pm 0.02 \mathrm{dpm} 100 \mathrm{~L}^{-1}, 2.62 \pm 0.15 \mathrm{dpm} 100 \mathrm{~L}^{-1}$, $5.15 \pm 0.80 \mathrm{dpm} 100 \mathrm{~L}^{-1}$, and $7.10 \pm 0.91 \mathrm{dpm} 100 \mathrm{~L}^{-1}$, respectively). Similarly, groundwater has high concentrations of nutrients, DIC, and TAlk compared with surface waters. Silicate displayed conservative mixing between a high groundwater end-member and much lower values in seawater. In contrast, $\mathrm{NH}_{4}^{+}, \mathrm{PO}_{4}^{3-}$, DIC, and TAlk showed increases while $\mathrm{NO}_{3}^{-}+\mathrm{NO}_{2}^{-}$showed decreases during the mixing of fresh groundwater with seawater in the coastal aquifer. Detailed descriptions of the concentrations of the solutes and their variability can be found in the Supplement. 


\section{Discussion}

\subsection{Water ages derived from ${ }^{223} \mathrm{Ra} /{ }^{228} \mathrm{Ra}$}

Water age is defined as the time a water parcel has spent since entering the estuary/ continental shelf through one of its boundaries (Charette et al., 2008). It is a key variable in understanding chemical and biological processes of riverine plumes and nearshore upwelling and also necessary to determine the fluxes of SGD and associated terrestrial materials. This can be estimated via physical methods (Pilson, 1985; Sanford et al., 1992), numerical models (Das et al., 2000), or isotopic water mass balances (Kelly and Moran, 2002; Delhez et al., 2003; Rasmussen, 2003). Radium isotopes have been used to estimate the time elapsed since a water parcel was last in contact with a boundary (Charette et al., 2008; Peterson et al., 2008b). Here, we used ${ }^{223} \mathrm{Ra} /{ }^{228} \mathrm{Ra}$ activity ratio (AR) to estimate the water age. The normalization to the long-lived ${ }^{228} \mathrm{Ra}$ was to eliminate the effect of mixing processes. In theory, ${ }^{224} \mathrm{Ra}$ can be used in place of ${ }^{223} \mathrm{Ra}$ as long as the water age is shorter than 10 days. However, ${ }^{224} \mathrm{Ra}$ was depleted in the offshore river plume (See Sect. 3.2.1), suggesting that ${ }^{224} \mathrm{Ra}$ was not appropriate to trace the Pearl River plume farther off the estuary due to its short half life (3.66 days). According to Moore (2000a) and Charette et al. (2001), the mathematical equation can be represented as:

$$
\left[\frac{\mathrm{ex}^{223} \mathrm{Ra}}{\mathrm{ex}^{228} \mathrm{Ra}}\right]_{\mathrm{obs}}=\left[\frac{\mathrm{ex}^{223} \mathrm{Ra}}{\mathrm{ex}^{228} \mathrm{Ra}}\right]_{\mathrm{i}} e^{-\lambda_{223} \tau}
$$

Where, ex represents the measured Ra concentration in excess of the value in the offshore surface water $(0.07 \mathrm{dpm}$ $100 \mathrm{~L}^{-1}$ for ${ }^{223} \mathrm{Ra}, 7.10 \mathrm{dpm} 100 \mathrm{~L}^{-1}$ for ${ }^{228} \mathrm{Ra}$ ); $\left[\frac{\mathrm{ex}^{223} \mathrm{Ra}}{\mathrm{ex}^{228} \mathrm{Ra}}\right]_{\mathrm{i}}$ denotes the initial activity ratio of the radium source; $\left[\frac{\mathrm{ex}^{223} \mathrm{Ra}}{\mathrm{ex}^{228} \mathrm{Ra}}\right]_{\mathrm{obs}}$ designates the activity ratio of water samples in the study area; $\lambda_{223}$ is the decay constant for ${ }^{223} \mathrm{Ra}$; and $\tau$ is the water age in the system. We neglected the decay of ${ }^{228} \mathrm{Ra}$ since $\lambda_{228}$ is much smaller than $\lambda_{223}$. In applying this equation it is assumed that the Ra activity ratio of the endmember remains constant and activities of ${ }^{223} \mathrm{Ra}$ and ${ }^{228} \mathrm{Ra}$ are mainly influenced by the dispersal of river plume on the NSCS shelf. Here, using the mean ex ${ }^{223} \mathrm{Ra} / \mathrm{ex}{ }^{228} \mathrm{Ra}$ AR of 0.054 in the Pearl River as an end-member, we obtained a similar ex ${ }^{223} \mathrm{Ra} / \mathrm{ex}{ }^{228} \mathrm{Ra}$ AR of 0.057 in the August 2008 cruise to the PRE (Dai, unpublished data). Another assumption is that there is no additional Ra input after the water parcel leaves the coast, which is valid in our case since the river plume enhanced the stratification and was therefore isolated from potential sources from the benthic sediments. However, one exception is the coastal upwelling zone, where the surface water was additionally influenced by subsurface water mixing, sediment diffusion and resuspension, and SGD with higher ${ }^{223} \mathrm{Ra} /{ }^{228} \mathrm{Ra} A R$ (Fig. 5). For the upwelling zones, we thus adopted the approach of Moore (2006) which considers continuous radium additions from sediments or SGD:

$$
\tau=\left[\mathrm{F}\left(\frac{{ }^{223} \mathrm{Ra}}{228 \mathrm{Ra}}\right)-\mathrm{I}\left(\frac{{ }^{223} \mathrm{Ra}}{228 \mathrm{Ra}}\right)\right] / \mathrm{I}\left(\frac{{ }^{223} \mathrm{Ra}}{228 \mathrm{Ra}}\right) \lambda_{223}
$$

Where, $\mathrm{F}\left(\frac{223 \mathrm{Ra}}{228 \mathrm{Ra}}\right)$ is the ${ }^{223} \mathrm{Ra} /{ }^{228} \mathrm{Ra}$ activity ratio (AR) in the input water, $\mathrm{I}\left(\frac{223 \mathrm{Ra}}{228 \mathrm{Ra}}\right)$ is the ${ }^{223} \mathrm{Ra} /{ }^{228} \mathrm{Ra} A \mathrm{AR}$ in the system. Here, we used the maximum ${ }^{223} \mathrm{Ra} /{ }^{228} \mathrm{Ra}$ AR of 0.06 in the upwelling zone for $\mathrm{F}\left(\frac{223 \mathrm{Ra}}{228 \mathrm{Ra}}\right)$. It should be noted that using this activity ratio for the input water might lead to an underestimate of the water age. For instance, at Site S701, which is $13 \mathrm{~km}$ offshore, there may exist further nearshore input with higher ${ }^{223} \mathrm{Ra} /{ }^{228} \mathrm{Ra}$ AR. Likely, ${ }^{224} \mathrm{Ra}$ can be used in place of ${ }^{223} \mathrm{Ra}$. To avoid the analytical uncertainties caused by different Ra ratios when estimating the water age, we used ${ }^{223} \mathrm{Ra} /{ }^{228} \mathrm{Ra}$ to estimate the water age both in the upwelling zone and in the river plume area.

Water ages thus determined are, on average, $14.3 \pm 10.2$ days on the NSCS shelf, $8.5 \pm 6.7$ days for the upwelled water, $12.3 \pm 4.6$ days for the river plume, and $16.3 \pm 10.3$ days for the NSCS shelf water outside the upwelling zone. The quoted age uncertainties represent one standard deviation associated with the spatial variations of the concerned area. Our evaluated average water age on the NSCS shelf is consistent with the physical modeling estimation (13.5 days) with the currents driven by idealized constant wind stress (Jianping Gan, Hong Kong University of Science and Technology, personal communication).

\subsection{Submarine groundwater discharge}

Figure 6 can be used to further examine various Ra sources. There were distinguishable $\mathrm{Ra}$ additions with regard to the conservative mixing line between the river and seawater endmembers (solid line in Fig. 6). In the PRE, these additions could be explained by ion exchange with suspended fluvial particles, diffusion from sediments, and SGD. After salinity driven desorption has run its course within the estuary, Ra should behave conservatively. Thus, unlike that in the estuary, there was no Ra peak at intermediate salinity on the NSCS shelf. The radium/salinity relationships also revealed other Ra sources. Elevated ex ${ }^{224} \mathrm{Ra}$ and ${ }^{223} \mathrm{Ra}$ were present at high salinity (33.3-34.0) where the influence of coastal upwelling was strong. Beyond the upwelling zone, excess ${ }^{223} \mathrm{Ra}$ can be contributed by SGD and diffusion from sediments, which was not apparent with ex ${ }^{224} \mathrm{Ra}$ in the shelf water probably due to faster decay during mixing. Alternatively, we believed that long-lived Ra isotopes could be unambiguous tracers of SGD in the NSCS mainly due to their long half-lives and proportionally less diffusion from sediments. Moreover, given that Ra was enriched in groundwater relative to the river plume and seawater, and Ra behaved conservatively after entering the marine water, we were able to use Ra isotopes as tracers to estimate the SGD flux, which is further discussed as follows. 


\subsubsection{SGD flux derived from a three end-member mixing model on the NSCS shelf}

By definition SGD includes meteoric water from land drainage and seawater that exchanges with the coastal aquifer (Burnett et al., 2003). Since the composition of these two SGD components was unknown and we had a limited number of groundwater samples, it was difficult to determine the average salinity of the SGD end-member. Our parallel study (Cao et al., 2011) have indicated that regional salinity normalized alkalinity is constant both in the river plume and the coastal upwelling zone, suggesting that alkalinity in the shelf water is conservative and is mainly controlled by physical mixing. Note that being conservative here refers to the absence of biogeochemical modification of alkalinity along the salinity gradient rather than that alkalinity is controlled solely by the mixing between seawater and river water. We identified four potential end-members contributing to alkalinity and radium isotopes in the NSCS surface water: the Pearl River plume, offshore surface SCS water, SGD, and offshore subsurface water. The source for the upwelled water is defined as the offshore subsurface water sourced from $\sim 150 \mathrm{~m}$ with a high salinity of 34.5 , a potential temperature of $17^{\circ} \mathrm{C}$ (Cao et al., 2011), Here we took ${ }^{228} \mathrm{Ra}$ activity $\left(5.52 \pm 0.94 \mathrm{dpm} 100 \mathrm{~L}^{-1}\right)$ and ${ }^{226} \mathrm{Ra}(5.82 \pm 0.63 \mathrm{dpm}$ $\left.100 \mathrm{~L}^{-1}\right)$ at $150 \mathrm{~m}$ depth from a cruise conducted in April, 2009 (Weifang Chen, unpublished data) as the offshore subsurface end-member. This water mass had end-member values of ${ }^{228} \mathrm{Ra},{ }^{226} \mathrm{Ra}$, and TAlk very similar to the offshore surface water as illustrated in Fig. 7a and b. This suggests that we can neglect the contribution of long-lived Ra and TAlk to surface water from upward diffusion and advection. Additionally, in our focused zone (mixed layer) excluding the nearshore upwelling area, the offshore surface water contributes $77 \%$ of the mass while the offshore subsurface water only contributes $1.5 \%$ to the shelf water based on the conservation of potential temperature and salinity (Cao et al., 2011; Han et al., 2012). This suggests once again that the subsurface water contribution is insignificant as compared to the offshore surface water. Finally, it was clear that from the TAlk versus long-lived Ra plots (Fig. 7), only very few data points fell on the two end-member mixing line between the river plume and the offshore surface water. Instead, most of the surface water samples were influenced by a third source characterized by high ${ }^{228} \mathrm{Ra},{ }^{226} \mathrm{Ra}$, and TAlk, which we infer to be SGD. Therefore, a three end-member mixing model was established as follows to estimate the SGD flux to the NSCS shelf excluding the upwelling zone.

$f_{\mathrm{S}}+f_{\mathrm{P}}+f_{\mathrm{GW}}=1$

${ }^{i} \operatorname{Ra}_{S} f_{\mathrm{S}}+{ }^{i} \operatorname{Ra} f_{\mathrm{P}}+{ }^{i} \operatorname{Ra} \mathrm{GW} f_{\mathrm{GW}}={ }^{i} \operatorname{Ra}_{\mathrm{M}}$

$\mathrm{TAlk}_{\mathrm{S}} f_{\mathrm{S}}+\mathrm{TAlk}_{\mathrm{P}} f_{\mathrm{P}}+\mathrm{TAlk}_{\mathrm{GW}} f_{\mathrm{GW}}=\mathrm{TAlk}_{\mathrm{M}}$
Where the subscripts $\mathrm{S}, \mathrm{P}$, and GW refer to the oceanic, Pearl River plume, and surficial groundwater end-members, respectively. The subscript $\mathrm{M}$ represents the measured values for individual samples, the parameter $f$ is fraction of water derived from the three end-members, the superscript $i$ is 226 or $228, \mathrm{Ra}$ is $\mathrm{Ra}$ isotope activity $\left(\mathrm{dpm} 100 \mathrm{~L}^{-1}\right)$ and TAlk is total alkalinity $\left(\mathrm{mmol} \mathrm{m}^{-3}\right)$. Radium-226 and ${ }^{228} \mathrm{Ra}$ decay is negligible on the time scale of mixing processes in the study region. In this model, the biggest uncertainty rested with $\mathrm{Ra}$ for the groundwater end-member, because we lacked brackish groundwater $\mathrm{Ra}$ samples in 2008. The ${ }^{228} \mathrm{Ra}$ activity in groundwater collected in 2008 and 2010 ranged from $30.2-872 \mathrm{dpm} 100 \mathrm{~L}^{-1}$ (Table S1 in the Supplement). Here we took the average of all the high ${ }^{228} \mathrm{Ra}\left(>400 \mathrm{dpm} 100 \mathrm{~L}^{-1}\right.$ ) samples in 2008 and 2010 as the groundwater end-member. Note that such a practice may underestimate SGD (See Sect. 4.2.3). For ${ }^{226} \mathrm{Ra}$, the average of $124 \pm 11 \mathrm{dpm} 100 \mathrm{~L}^{-1}$ in 2008 was used as the groundwater end-member since we did not measure ${ }^{226} \mathrm{Ra}$ for groundwater in 2010 . For TAlk, we took the average from all groundwater $\left(4020 \mathrm{mmol} \mathrm{m}^{-3}\right)$ sampled in 2008 and 2010 as the end-member value. The values of TAlk, ${ }^{226} \mathrm{Ra}$, and ${ }^{228} \mathrm{Ra}$ for the three end-members were listed in Table 2.

The model results were shown in Fig. 8. The groundwater fraction in the NSCS $\left(f_{\mathrm{G} W}\right)$ fell in the range of 0 to $5 \%$ (mean $1.5 \pm 1.6 \%$ ) based on the ${ }^{228} \mathrm{Ra} / \mathrm{TAlk}$ relationship and $0-9.7 \%$ (mean $2.5 \pm 2.6 \%$ ) using the ${ }^{226} \mathrm{Ra} / \mathrm{TAlk}$ relationship. The Pearl River plume contribution to shelf waters spanned from nil to $83 \%$, with an average of $38 \%$.

We also calculated the volumetric discharge rate of SGD $\left(\mathrm{m}^{3} \mathrm{~d}^{-1}\right)$ on the NSCS shelf using the formula:

$\mathrm{SGD}=f_{\mathrm{G} W} \times \mathrm{V}_{\mathrm{SW}} / \tau$

Where $V_{S W}$ is the water volume above the mixed layer in the study region $\left(\mathrm{m}^{3}\right)$ and $\tau$ is the radium-derived water age (days). Using $245 \mathrm{~km}^{3}$ for $\mathrm{V}_{\mathrm{SW}}$ and $16.3 \pm 10.3$ days for $\tau$, as derived from the ${ }^{223} \mathrm{Ra} /{ }^{228} \mathrm{Ra}$ AR age model, the SGD fluxes from the ${ }^{228} \mathrm{Ra}$-TAlk and ${ }^{226} \mathrm{Ra}$-TAlk mixing models were calculated to be $2.3 \pm 2.8 \times 10^{8}$ and $3.7 \pm 4.6 \times 10^{8} \mathrm{~m}^{3} \mathrm{~d}^{-1}$, respectively.

\subsubsection{Radium mass balance approach for estimating SGD}

Our second approach to quantify the SGD fluxes is based on Ra mass balance, which has been frequently used (Charette et al., 2008 and reference therein), as illustrated in Fig. 9. Under steady state, Ra inventory is sustained by constant supply of $\mathrm{Ra}$ from all sources, which can be expressed as follows:

$$
\begin{aligned}
& \frac{\text { Inventory }{ }^{i} \mathrm{Ra}}{\tau}=\left[\mathrm{F}_{\mathrm{Riv}} \times{ }^{i} \mathrm{Ra}_{\mathrm{Riv}}\right] \\
& +\left[\mathrm{A}_{\mathrm{Sed}} \times{ }^{i} \mathrm{Ra} \mathrm{Sed}_{\mathrm{Sed}}\right]+\left[\mathrm{SGD} \times{ }^{i} \mathrm{Ra}_{\mathrm{Gw}}\right]+\left[v \times{ }^{i} \mathrm{Ra}_{\mathrm{Uw}} \times A_{\mathrm{Uw}}\right]
\end{aligned}
$$

where, the left term is the total Ra input (or output) flux, and the right terms represent various Ra sources including the 

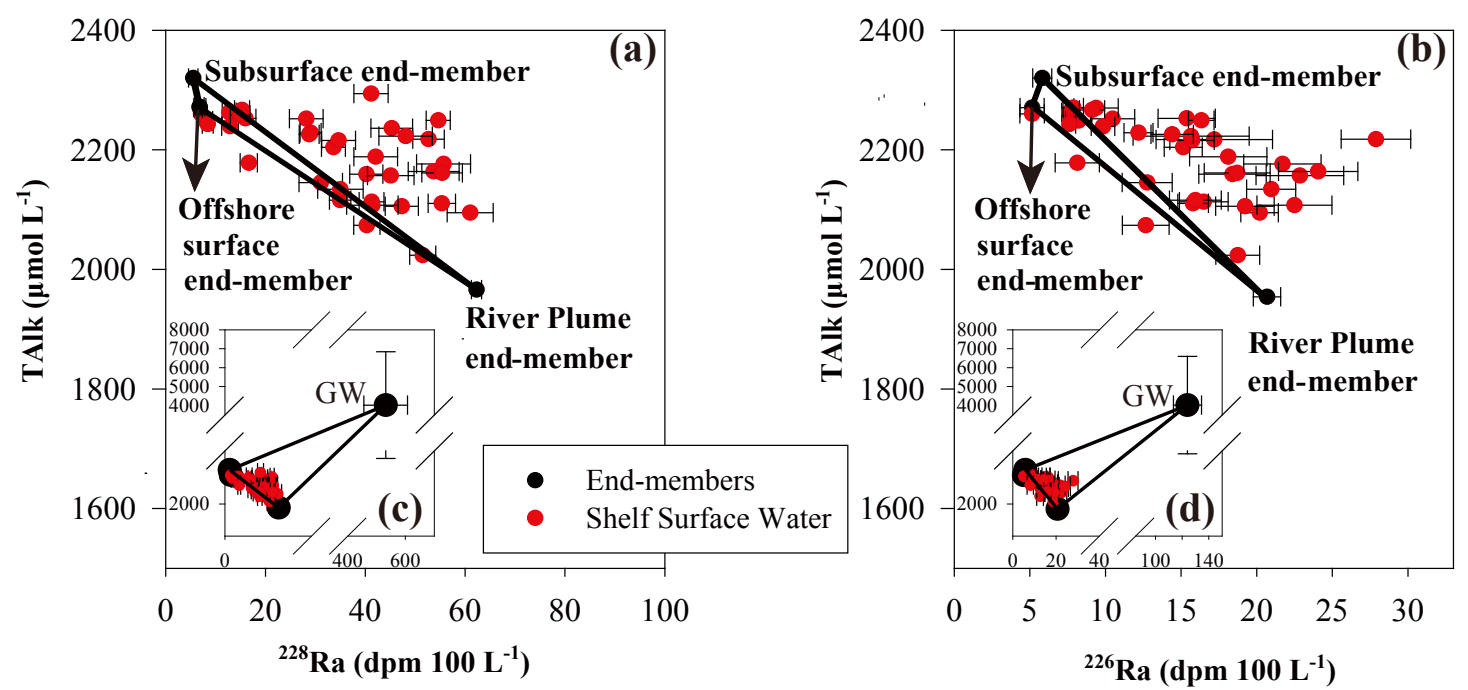

Fig. 7. Total alkalinity (TAlk) versus ${ }^{228} \mathrm{Ra}(\mathbf{a})$ and ${ }^{226} \mathrm{Ra}$ (b) in the surface water of the northern South China Sea excluding the nearshore upwelling zone. Surface water samples were taken from 30 June-8 July, 2008. Subsurface end-member values for ${ }^{228} \mathrm{Ra}$ and ${ }^{226} \mathrm{Ra}$ activity were based on the measurements at $150 \mathrm{~m}$ depth in the same region from a cruise conducted in April, 2009. Also shown are the individual end-member values for the three end-member mixing model (c and d). The average groundwater (GW) end-member values for ${ }^{228} \mathrm{Ra}$ and ${ }^{226} \mathrm{Ra}$ were sampled in December 2008 and October 2010, respectively. Red circles represent the surface data, and the error bars are associated analytical errors. Black circles represent end-member values for river plume, offshore subsurface water, offshore surface water, and average GW, where the error bars reflect the spatial variation $( \pm 1 \sigma)$.

Table 2. End-member values used for ${ }^{226}$ Ra-TAlk and ${ }^{228}$ Ra-TAlk three end-member mixing model to estimate submarine groundwater discharge flux to the northern South China Sea.

\begin{tabular}{llll}
\hline End-members & $\begin{array}{l}{ }^{226} \mathbf{R a} \\
\left(\mathrm{dpm} 100 \mathrm{~L}^{-1}\right)\end{array}$ & $\begin{array}{l}{ }^{228} \mathbf{R a} \\
\left(\mathrm{dpm} 100 \mathrm{~L}^{-1}\right)\end{array}$ & $\begin{array}{l}\text { TAlk } \\
\left(\mathrm{mmol} \mathrm{m}^{-3}\right)\end{array}$ \\
\hline Offshore surface water & $5.15 \pm 0.80$ & $7.10 \pm 0.92$ & 2272 \\
Pearl River plume & $20.68 \pm 0.90$ & $62.29 \pm 1.01$ & 1966 \\
Groundwater & $124.02 \pm 10.57$ & $531.8 \pm 15.2$ & 4020 \\
\hline
\end{tabular}

contributions from dissolved Ra and release from suspended particles in the Pearl River water, benthic diffusional flux, SGD, and coastal upwelling input. Since SGD is the only unknown in Eq. (7), it can be calculated. We considered two scenarios in this box model calculation: with and without upwelling. Summarized in Table 4 are the definitions, values and units of the terms involved in the box model.

The discharge rate of the Pearl River was the sum of the average discharge rates of the three tributaries one week prior to the sampling. For the SGD calculation, we only estimated the groundwater input along the coastline but excluded the SGD from PRE. Both ${ }^{228} \mathrm{Ra}$ and ${ }^{226} \mathrm{Ra}$ were approximately conservative at salinity $>9$ in the PRE (Fig. $6 \mathrm{c}$ and d), and thus we used the Ra functions with salinity (equations shown in Fig. $6 c$ and d) to obtain the effective Ra activities at the river end-members of nil salinity which allowed for an estimate of Ra fluxes delivered by the Pearl River both in the dissolved form and those released from suspended particles.
Two surface sediment samples taken near S201 were mainly composed of different sizes of sands and small amounts of silts, which are consistent with sediment type reported for the NSCS (Hiroshi and Emery, 1961; Luo et al., 1985; Zhang et al., 2003). We did not perform sediment incubation experiments to directly measure the diffusive Ra flux, but instead took the average from the globally available regeneration rate of 0.45 and $25 \mathrm{dpm} \mathrm{m}^{-2}$ day $^{-1}$ for ${ }^{226} \mathrm{Ra}$ and ${ }^{228} \mathrm{Ra}$ (Krest et al., 1999; Hancock et al., 2000; Charette et al., 2001; Hancock et al., 2006), respectively. The reported average activities for ${ }^{226} \mathrm{Ra},{ }^{228} \mathrm{Ra}$, and ${ }^{228} \mathrm{Th}$ in NSCS surface sediments are $1.66 \pm 0.08,2.70 \pm 0.35,2.52 \pm 0.36 \mathrm{dpm} \mathrm{g}^{-1}$, respectively (Liu et al., 2001). As these activities are typical of the other studies cited above, we are confident that the potential diffusive Ra fluxes are small. We calculated the volume subject to upwelling by multiplying the surface area with the water depth of the upwelling zone. The ${ }^{228} \mathrm{Ra}$ and ${ }^{226} \mathrm{Ra}$ activities at $150 \mathrm{~m}$ depth from a cruise conducted in 


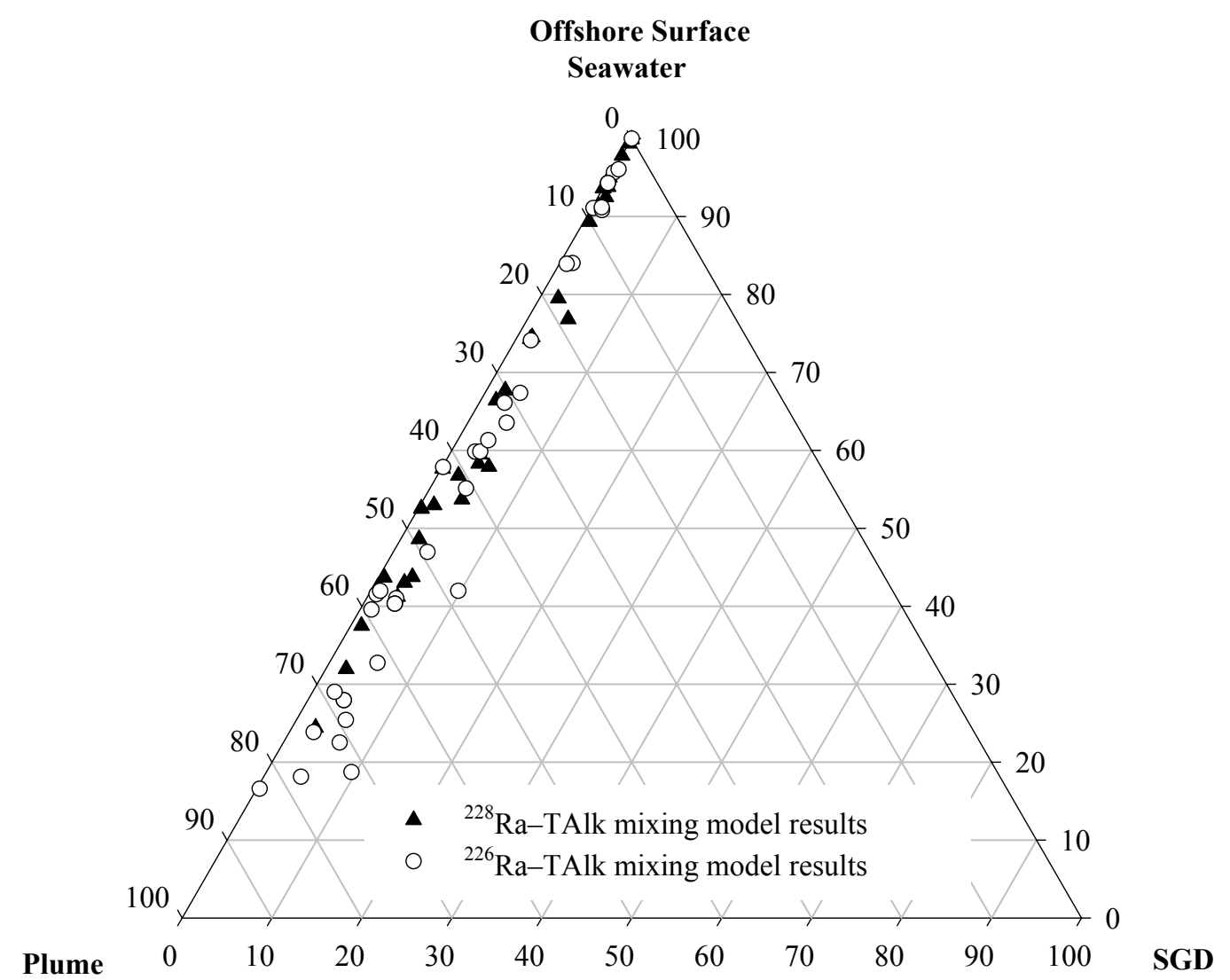

Fig. 8. Ternary diagram illustrating simulated percentage contributions from submarine groundwater discharge (SGD), offshore surface water, and Pearl River plume for surface water of the northern South China Sea for the period 30 June-8 July, 2008 using a three end-member mixing model based on ${ }^{228} \mathrm{Ra}$ and total alkalinity (TAlk), and ${ }^{226} \mathrm{Ra}-\mathrm{TAlk}$.

Table 3. Submarine groundwater discharge (SGD) estimated based on a three end-member mixing model and Ra mass balance in the northern South China Sea. Also shown are the sensitivity analysis and error sources with different methods.

\begin{tabular}{|c|c|c|c|c|c|}
\hline & Method & SGD & \multicolumn{2}{|c|}{ Error Source } & \multirow{2}{*}{$\begin{array}{l}\text { Uncertainty }(\%) \\
\begin{array}{c}3.6-3.8^{*} \\
6.3-7.1^{*} \\
1.3-3.1^{*}\end{array}\end{array}$} \\
\hline $\begin{array}{l}\text { Three } \\
\text { end-member }\end{array}$ & ${ }^{228} \mathrm{Ra}$ and TAlk & $23 \pm 28$ & $\begin{array}{c}\mathrm{Ra} \\
\text { end-member }\end{array}$ & $\begin{array}{l}\text { groundwater } \\
\text { river plume } \\
\text { offshore }\end{array}$ & \\
\hline mixing model & ${ }^{226} \mathrm{Ra}$ and TAlk & $37 \pm 46$ & $\begin{array}{c}\text { TAlk } \\
\text { end-member }\end{array}$ & $\begin{array}{l}\text { groundwater } \\
\text { river plume } \\
\text { offshore }\end{array}$ & $\begin{array}{c}6.0-7.5^{*} \\
59.5-72.5^{*} \\
59.6-75.2^{*}\end{array}$ \\
\hline Ra Mass & $\begin{array}{l}{ }^{228} \mathrm{Ra} \text { with upwelling } \\
{ }^{226} \mathrm{Ra} \text { with upwelling }\end{array}$ & $\begin{array}{l}34 \pm 58 \\
37 \pm 46\end{array}$ & $\begin{array}{c}\mathrm{Ra} \\
\text { end-member }\end{array}$ & $\begin{array}{l}\text { groundwater } \\
\text { river plume } \\
\text { offshore } \\
\text { upwelling }\end{array}$ & $\begin{array}{c}4.8^{*} \\
15.5-44.1^{*} \\
19.3-27.6^{*} \\
3.6-4.1^{*}\end{array}$ \\
\hline Balance & $\begin{array}{l}{ }^{228} \mathrm{Ra} \text { without upwelling } \\
{ }^{226} \mathrm{Ra} \text { without upwelling }\end{array}$ & $\begin{array}{l}22 \pm 43 \\
33 \pm 53\end{array}$ & \multicolumn{2}{|c|}{$\begin{array}{l}\text { Mixed layer depth } \\
\text { Water age }\end{array}$} & $\begin{array}{c}0.1-2.7 \text { (depth changes } 1 \mathrm{~m} \text { ) } \\
20.6-25.9 \text { (varying } 1 \text { day) } \\
4.0^{*}\end{array}$ \\
\hline
\end{tabular}

* represents $5 \%$ variation with each error source. 
Table 4. Definitions and values used for ${ }^{226} \mathrm{Ra}$ and ${ }^{228} \mathrm{Ra}$ mass balance to estimate submarine groundwater discharge flux to the northern South China Sea.

\begin{tabular}{|c|c|c|c|c|}
\hline & Definition & ${ }^{226} \mathrm{Ra}$ & ${ }^{228} \mathrm{Ra}$ & Unit \\
\hline Ra Riv & Ra end-member in the Pearl River estuary & $34.7 \pm 1.58$ & $95.7 \pm 4.66$ & $\mathrm{dpm} 100 \mathrm{~L}^{-1}$ \\
\hline $\mathrm{Ra}_{\mathrm{Gw}}$ & Average activity of $\mathrm{Ra}$ in the groundwater & $124.0 \pm 10.57$ & $531.8 \pm 15.21$ & dpm $100 \mathrm{~L}^{-1}$ \\
\hline $\mathrm{Ra}_{\mathrm{Off}}$ & Ra activity in the offshore surface water & $5.15 \pm 0.80$ & $7.10 \pm 0.92$ & dpm $100 \mathrm{~L}^{-1}$ \\
\hline$\tau$ & Water age & \multicolumn{2}{|c|}{$16 \pm 10^{*}$} & days \\
\hline$F_{\text {Riv }}$ & Discharge of the Pearl River & \multicolumn{2}{|c|}{$1.76 \times 10^{9}$} & $\mathrm{~m}^{3} \mathrm{~d}^{-1}$ \\
\hline$A_{\text {Sed }}$ & Surface area of benthic sediment & \multicolumn{2}{|c|}{$3.08 \times 10^{10}$} & $\mathrm{~m}^{2}$ \\
\hline Rased & Diffusive benthic flux of $\mathrm{Ra}$ & 0.45 & 25 & $\mathrm{dpm} \mathrm{m} \mathrm{m}^{-2} \mathrm{~d}^{-1}$ \\
\hline $\mathrm{H}$ & Mixed layer depth & \multicolumn{2}{|c|}{$5-30$} & $\mathrm{~m}$ \\
\hline $\mathrm{Ra}_{\mathrm{Uw}}$ & Average activity of Ra in the subsurface offshore water & $5.82 \pm 0.63$ & $5.52 \pm 0.94$ & dpm $100 \mathrm{~L}^{-1}$ \\
\hline $\mathrm{A}_{\mathrm{Uw}}$ & Surface area of the upwelling zone & \multicolumn{2}{|c|}{$1.99 \times 10^{9}$} & $\mathrm{~m}^{2}$ \\
\hline $\mathrm{v}$ & Upwelling rate & \multicolumn{2}{|c|}{1.7} & $\mathrm{md}^{-1}$ \\
\hline
\end{tabular}

* represents no upwelling; \# denotes with upwelling.

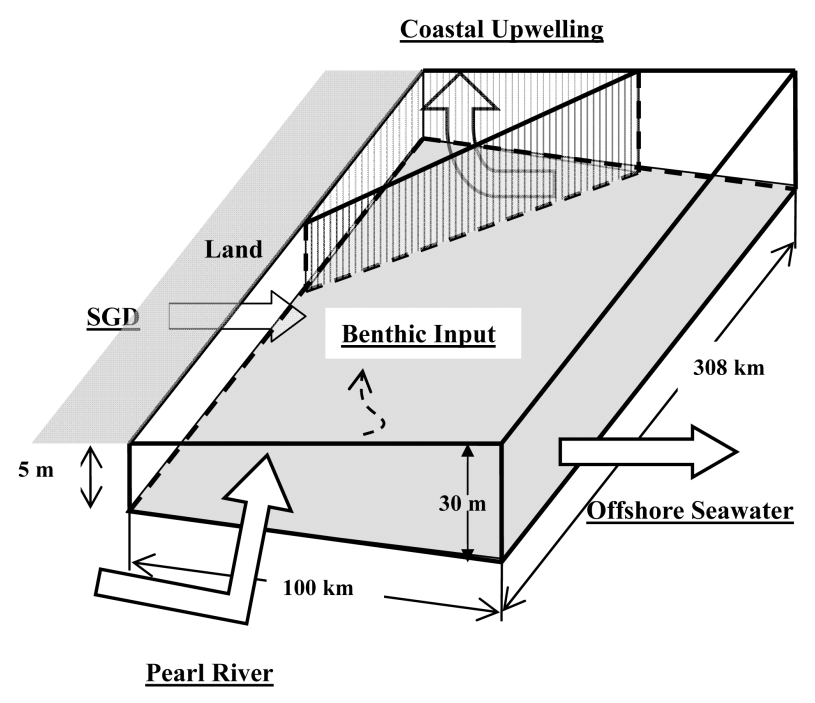

Fig. 9. Schematic of a mass balance box model of long-lived Ra isotopes $\left({ }^{228} \mathrm{Ra}\right.$ and ${ }^{226} \mathrm{Ra}$ ) on the northern South China Sea shelf covering the seven cross-shelf transects (see Fig. 1) extending $308 \mathrm{~km}$ alongshore, $100 \mathrm{~km}$ offshore, with mixed layer depths from 5 to $30 \mathrm{~m}$. Sources of Ra include Pearl River, benthic input, coastal upwelling and submarine groundwater discharge (SGD).

April, 2009 (Weifang Chen, unpublished data) were used as the end-member values for the offshore subsurface water.

In our Ra inventory estimation, we did not take into account the whole water column but only used a single surface sample to represent the whole mixed layer because not enough bottom samples were collected. During our cruise, the water column was well stratified from the underlying waters influenced by the strong river plume. This stratification would limit the impact of the offshore groundwater (if any) on the surface seawater. Therefore, in this study we primarily focused on nearshore groundwater. Excess Ra was obtained by subtracting the values in the offshore surface water $\left(5.15 \pm 0.80 \mathrm{dpm} 100 \mathrm{~L}^{-1}\right.$ for ${ }^{226} \mathrm{Ra}, 7.10 \pm 0.92 \mathrm{dpm}$ $100 \mathrm{~L}^{-1}$ for ${ }^{228} \mathrm{Ra}$ ) from the measured activity on the NSCS shelf. Following Moore (2007) for the southeastern U.S. continental shelf, we derived excess Ra inventory normalized to shoreline length $\left(\mathrm{dpm} \mathrm{km}^{-1}\right)$ for transects from 2 to 7 in the zones with and without upwelling. Then, the excess Ra inventory (dpm) was determined from the average Ra inventory in two adjacent transects multiplied by the length of coastal line between the two transects. These inventories were summarized to yield total excess Ra inventory in the NSCS.

Table 5 summarized all the sources that contribute to the total ${ }^{226} \mathrm{Ra}$ and ${ }^{228} \mathrm{Ra}$ in the NSCS, among which, dissolved Ra plus Ra desorbed from suspended particles from Pearl River accounted for $37-59 \%$ of the total Ra flux, which was comparable to the SGD contribution of $32-41 \%$. This was in contrast to non river-dominated marginal systems where input from SGD dominates the total Ra flux in the coastal ocean (e.g. Moore et al., 2007).

Our estimated SGD fluxes without upwelling were $2.2 \times 10^{8}$ and $3.3 \times 10^{8} \mathrm{~m}^{3} \mathrm{~d}^{-1}$ based on the mass balance of ${ }^{228} \mathrm{Ra}$ and ${ }^{226} \mathrm{Ra}$, respectively. With the upwelling zone included, we calculated slightly higher SGD fluxes of $3.4 \times 10^{8}$ and $3.7 \times 10^{8} \mathrm{~m}^{3} \mathrm{~d}^{-1}$ based on ${ }^{228} \mathrm{Ra}$ and ${ }^{226} \mathrm{Ra}$, respectively.

\subsubsection{Comparison of the two methods for estimating SGD}

Comparing these two approaches, we obtained average SGD fluxes of $3.0 \pm 2.7 \times 10^{8} \mathrm{~m}^{3} \mathrm{~d}^{-1}$ and $2.8 \pm 3.4 \times 10^{8} \mathrm{~m}^{3} \mathrm{~d}^{-1}$ (excluding the nearshore upwelling zone) via the Ra-TAlk three end-member mixing model and Ra mass balance 
Table 5. Fractional contributions of various sources to the total ${ }^{226} \mathrm{Ra}$ and ${ }^{228} \mathrm{Ra}$ flux into the northern South China Sea shelf.

\begin{tabular}{lcccc}
\hline \multirow{2}{*}{ Method } & River & Sediment & Groundwater & Upwelling \\
\cline { 2 - 5 } & Dissolved Ra + suspended particles release & & & \\
\hline${ }^{228} \mathrm{Ra}$ Mass Balance (NU) & $46 \%$ & $21 \%$ & $32 \%$ & - \\
${ }^{226} \mathrm{Ra}$ Mass Balance (NU) & $59 \%$ & $1 \%$ & $40 \%$ & - \\
${ }^{228} \mathrm{Ra}$ Mass Balance (WU) & $37 \%$ & $18 \%$ & $41 \%$ & $4 \%$ \\
${ }^{226} \mathrm{Ra}$ Mass Balance (WU) & $48 \%$ & $1 \%$ & $35 \%$ & $16 \%$ \\
\hline
\end{tabular}

NU represents no upwelling; WU denotes with upwelling.

model, respectively. The good agreement between these two independent methods gives us confidence that our estimated SGD fluxes are well grounded. The SGD fluxes for the $308 \mathrm{~km}$ NSCS coastline ranged from $3.4-3.7 \times 10^{8} \mathrm{~m}^{3} \mathrm{~d}^{-1}$ when the upwelling zone was included (Table 3 ). When scaled to the coastline length, the SGD rate was 1104$1201 \mathrm{~m}^{3} \mathrm{~m}^{-1} \mathrm{~d}^{-1}$. Our values were comparable to those from some other regional-scale studies, such as the South Atlantic Bight (5.5-6.2 $\times 10^{8} \mathrm{~m}^{3} \mathrm{~d}^{-1}$; Moore, 2010b) and Sicily/Mediterranean $\left(1000 \mathrm{~m}^{3} \mathrm{~m}^{-1} \mathrm{~d}^{-1}\right.$; Moore, 2006).

The three end-member mixing model was very sensitive to the end-member of river plume and offshore surface water values. For example, a $5 \%$ decrease in TAlk can change the SGD flux by $59.5-75.2 \%$ (Table 3). We have reported in Cao et al. (2011) that TAlk of these two end-members was relatively constant with only a $0.95-1.75 \%$ variation. The most variable end-members were TAlk and Ra in coastal groundwaters. However, our model was much less sensitive to changes in this term (6.0-7.5\% SGD change with $5 \%$ end-member variation). The higher the TAlk/Ra end-member for groundwater, the lower the SGD flux would be obtained. TAlk in groundwater had a large spatial variation, ranging from 381 to $9009 \mu \mathrm{mol} \mathrm{L}^{-1}$ (Table S1 in the Supplement). However, the SGD flux would change by $61 \%$ with the usage of the maximum TAlk compared with the average, a change that is within the bounds of the error estimation of the model. Notably, the re-estimated SGD would not change within uncertainties even when the groundwater Ra end-member was increased by $300 \%$, which already covered the spatial variation of Ra end-member values used in the three end-member mixing model.

Uncertainty analysis exhibited that the Ra mass balance was highly sensitive to the water age (Table 3 ). A variation of 1 day would cause a change of $21-26 \%$ in the SGD flux. It should be noted that the average water age in our study area has a standard deviation of $\sim 10$ days, which could produce one order of magnitude change in SGD flux estimations. However, much of this variability is likely natural, as water age is expected to vary with distance from the coastline, and given the scale of our model domain we do not feel that this is a major source of uncertainties in our SGD estimates. The uncertainty from benthic flux was small for ${ }^{226} \mathrm{Ra}$ due to its long half-life, but it might be significant for the ${ }^{228} \mathrm{Ra}$ model.
As presented in Table 5, the ${ }^{228} \mathrm{Ra}$ flux from benthic diffusion contributed $21 \%$ and $18 \%$ of total ${ }^{228} \mathrm{Ra}$ flux in our model without and with upwelling, respectively. Given that these estimates are obtained from the literature and applied to our study, the ${ }^{226} \mathrm{Ra}$ balance model should be considered to be more reliable than the ${ }^{228} \mathrm{Ra}$ model in this regard. Though our upwelling-derived Ra flux was not well constrained, our Ra box model was not sensitive to this Ra source. For example, a $5 \%$ change in Ra can only change the SGD flux by $3.6-4.1 \%$ (Table 3 ). Like the three end-member mixing model, the uncertainty from the Ra activity in groundwater was small $(4.8 \%$ SGD flux change with $5 \%$ end-member variation). Other error sources, such as Ra end-members in the offshore surface water and the river plume, are relatively easy to determine.

In general, $\mathrm{Ra}$ is usually enriched in brackish groundwater relative to fresh groundwater (Mulligan and Charette, 2006) due to cation exchange processes ( $\mathrm{Li}$ et al., 1977). For example, ${ }^{228} \mathrm{Ra}$ activities increase 100-fold when fresh groundwater mixes with seawater in the subterranean estuary (Moore et al., 2008). However, in some cases, high Ra activities in fresh groundwater have also been reported (Moore, 2003; Charette and Buesseler, 2004). High ${ }^{228}$ Ra activity existed in fresh groundwater in 2008, concurrently with our cruise, and in brackish groundwater in 2010, suggesting that our Raderived SGD flux represented the total SGD flux of fresh and brackish groundwater. The average net annual groundwater recharge rate is $1-1.8 \times 10^{7} \mathrm{~m}^{3}$ day $^{-1}$ into the groundwater system along the shoreline of our study site from 1956 to 2000 (Liao et al., 2005; Chen, 2008), which is only 3-8\% of our estimated SGD. Our data therefore suggest that most of the SGD came from recirculated seawater.

\subsection{SGD-induced nutrient and DIC fluxes on the NSCS shelf}

The nutrient fluxes contributed from saline SGD can be calculated by multiplying the Ra-derived SGD flux by the nutrient concentration difference between saline groundwater and seawater. There existed large spatial variations in nutrient concentrations in the saline groundwater (Table S1 in the Supplement), ranging from 57.4 to $579 \mu \mathrm{mol} \mathrm{L}^{-1}$, with an average of $256 \mu \mathrm{mol} \mathrm{L}^{-1}$ for dissolved inorganic 
nitrogen (DIN), and from 0.12 to $19 \mu \mathrm{mol} \mathrm{L}^{-1}$, with an average of $6.4 \mu \mathrm{mol} \mathrm{L}^{-1}$ for dissolved $\mathrm{PO}_{4}^{3-}$. In the following calculation, we used the average and minimum nutrient concentrations in the groundwater as end-members. We estimated nutrient inputs to the NSCS from SGD of $8-28 \times 10^{9} \mathrm{~mol} \mathrm{yr}^{-1}$ for DIN and $3-68 \times 10^{7} \mathrm{~mol} \mathrm{yr}^{-1}$ for $\mathrm{PO}_{4}^{3-}$. These were equivalent to $10-36 \%, 3-75 \%$ of the inputs of the Pearl River for DIN and $\mathrm{PO}_{4}^{3-}$, respectively, during the sampling period.

DIC concentration ranged from 2.9 to $8.7 \mathrm{mmol} \mathrm{L}^{-1}$, and the mean value was $5.1 \mathrm{mmol} \mathrm{L}^{-1}$ in the saline groundwater. TAlk ranged from 2.7 to $9.0 \mathrm{mmol} \mathrm{L}^{-1}$ with an average of $5.2 \mathrm{mmol} \mathrm{L}^{-1}$ in the saline groundwater. Using the same approach as for nutrients, we obtained a SGD contribution to the NSCS shelf of $153-347 \times 10^{9} \mathrm{~mol} \mathrm{yr}^{-1}$ for DIC and $127-319 \times 10^{9} \mathrm{~mol} \mathrm{yr}^{-1}$ for TAlk, which represented 23$53 \%$ and $20-51 \%$ of the riverine DIC and TAlk fluxes, respectively. Our estimate is similar to the DIC flux to the South Atlantic Bight by groundwater flow into salt marshes, where the average DIC concentration is $5 \mathrm{mmol} \mathrm{L}^{-1}$, and SGD delivered DIC flux is $235 \times 10^{9} \mathrm{~mol} \mathrm{yr}^{-1}$ (Cai et al., 2003). For smaller (local)-scale sites where groundwatersurface water DIC fluxes have been quantified, the average DIC is $16 \mathrm{mmol} \mathrm{L}^{-1}$ in the groundwater, SGD-derived DIC is $0.5 \times 10^{9} \mathrm{~mol} \mathrm{yr}^{-1}$ in the Okatee estuary (Moore et al., 2006).

Once released to surface water, SGD-derived DIC could be consumed by biological production stimulated by the nutrients supplied from groundwater. The net effect on the inorganic carbon budget in the coastal ocean from SGD will therefore be modulated by a balance between these two processes. Biological productivity in the Pearl River plume over the NSCS shelf is characterized by P limitation (Han et al., 2012). Based on the Redfield Ratio, SGDderived $\mathrm{P}$ may be responsible for a new production up to $0.3-$ $6.3 \mathrm{mmol} \mathrm{C} \mathrm{m}^{-2} \mathrm{~d}^{-1}$. This rate of new production would at most reduce the DIC flux by $3-72 \times 10^{9} \mathrm{~mol} \mathrm{Cyr}^{-1}$, which was $11 \%$ of the SGD-driven DIC flux. If we assume that the water volume of the mixed layer is $311 \mathrm{~km}^{3}$ and the average water age is 14.3 days, then SGD inputs could support DIC and TAlk increases of $19-44 \mu \mathrm{mol} \mathrm{L}^{-1}$ and $16-40 \mu \mathrm{mol} \mathrm{L}-1$ on the NSCS shelf, respectively. Since water column DIC concentrations could also be affected by gas exchange, these values represent the upper limits. Nevertheless, we conclude that SGD in our system is a net source of DIC and TAlk and it likely plays a significant role in the carbonate system over the NSCS shelf.

\section{Conclusions}

This study demonstrated that SGD can be a significant source of inorganic carbon to a RioMar shelf subject to abundant freshwater input from large rivers. The complex hydrogeologic regime in these systems requires multiple trac- ers in order to differentiate the multiple source terms including surface and groundwater inputs as well as subsurface water via upwelling. To this end, our study highlights the feasibility of using radium isotopes combined with TAlk to estimate SGD fluxes. The independent approaches we adopted based on three end-member mixing and mass balance have revealed consistent estimates for SGD, which were $2.3-3.7 \times 10^{8} \mathrm{~m}^{3} \mathrm{day}^{-1}$ and $2.2-3.7 \times 10^{8} \mathrm{~m}^{3} \mathrm{day}^{-1}$, respectively. These fluxes were equivalent to $12-21 \%$ of the Pearl River discharge in summer, 2008.

We estimate that DIC flux carried by SGD represents 23$53 \%$ of the DIC contributions from the Pearl River. To our knowledge, this is the first evaluation of SGD flux and its impact on the budget of coastal inorganic carbon in a riverdominated marginal system. Such an export of DIC from the groundwater may have significant impact on the carbonate system over the shelf. We also note that, since SGD also carries nutrients, the net effect of this DIC flux on the seawater DIC balance may be reduced. The interplay between the DIC and nutrient discharges will therefore depend on the hydrographic setting and the groundwater sources as well as the biogeochemical reactions taking place in the subsurface. Constraint of such end-members and their biogeochemical reactivity within coastal aquifers remains a big challenge for studying SGD. Despite these uncertainties, however, we contend that SGD-associated carbon fluxes cannot be neglected in regional and global carbon budgets.

\section{Supplementary material related to this article is available online at: http://www.biogeosciences.net/9/ 1777/2012/bg-9-1777-2012-supplement.pdf.}

\begin{abstract}
Acknowledgements. This work was financially supported by the National Basic Research Program of China (973 Program) through grant \#2009CB421204 and \#2009CB421201, and by the Natural Science Foundation of China (NSFC) through grants \#90711005, \#41121091 and \#41130857. Matthew Charette's participation was supported by a grant from the U.S. National Science Foundation (\#OCE-0751525). The sampling cruise was supported by the SCOPE project co-organized by Jiang Zhu, Dongxiao Wang, Xiaogang Guo, Minhan Dai and Jianping Gan. We are grateful to Qian Li, Minquan Guo, Yang Liu, Wenbin Zou, Nan Zheng, Jianrong Lin, Yuancheng Su, Xiao Huang, Lifang Wang, Hua Lin, and Zhangyong Wang for their help with ancillary data and sample collection. We also thank the crew of Shiyan III for their assistance at sea and Zhaoying Li for the help in the graphic work.
\end{abstract}

Edited by: C. P. Slomp 


\section{References}

Bokuniewicz, H., Taniguchi, M., Ishitoibi, T., Charette, M., Allen, M., and Kontar, E. A.: Direct measurements of submarine groundwater discharge (SGD) over a fractured rock aquifer in Flamengo Bay Brazil, Estuar. Coast. Shelf S., 76, 466-472, 2008.

Burnett, W. C., Bokuniewicz, H., Huettel, M., Moore, W. S., and Taniguchi, M.: Groundwater and pore water inputs to the coastal zone, Biogeochemistry, 66, 3-33, 2003.

Burnett, W. C., Chanyotha, S., Wattayakorn, G., Taniguchi, M., Umezawa, Y., and Ishitobi, T.: Underground sources of nutrient contamination to surface waters in Bangkok, Thailand, Sci. Total. Environ., 407, 3198-3207, 2009.

Cai, W.-J., Wang, Y.-C., Krest, J., and Moore, W. S.: The geochemistry of dissolved inorganic carbon in a surficial groundwater aquifer in North Inlet, South Carolina, and the carbon fluxes to the coastal ocean, Geochim. Cosmochim. Acta., 67, 631-639, 2003.

Cao, Z., Dai, M., Zheng, N., Wang, D., Li, Q., Meng, F., and Gan, J.: Dynamics of the carbonate system in a large continental shelf system under the influence of both a river plume and coastal upwelling, J. Geophys. Res., 116, G02010, doi:02010.01029/02010JG001596, 2011.

Capone, D. G. and Bautista, M.: A groundwater source of nitrate in nearshore marine sediments, Nature, 313, 214-216, 1985.

Charette, M. A.: Hydrologic forcing of submarine groundwater discharge: Insight from a seasonal study of radium isotopes in a groundwater-dominated salt marsh estuary, Limnol. Oceanogr., 52, 230-239, 2007.

Charette, M. A. and Buesseler, K. O.: Submarine groundwater discharge of nutrients and copper to an urban subestuary of Chesapeake Bay (Elizabeth River), Limnol. Oceanogr., 49, 376-385, 2004.

Charette, M. A., Buesseler, K. O., and Andrews, J. E.: Utility of radium isotopes for evaluating the input and transport of groundwater-derived nitrogen to a Cape Cod estuary, Limnol. Oceanogr., 46, 465-470, 2001.

Charette, M. A., Splivallo, R., Herbold, C., Bollinger, M. S., and Moore, W. S.: Salt marsh submarine groundwater discharge as traced by radium isotopes, Mar. Chem., 84, 113-121, 2003.

Charette, M. A., Moore, W. S., and Burnett, W. C.: Uranium-and thorium-series nuclides as tracers of submarine groundwater discharge, in: U-Th series Nuclides in Aquatic systems, edited by: Krishnaswami, S., Cochran, J. K., Amsterdam, The Netherlands, Elsevier, 13, 155-191, 2008.

Chen, W., Liu, Q., Huh, C.-A., Dai, M., and Miao, Y.-C.: Signature of the Mekong River plume in the western South China Sea revealed by radium isotopes, J. Geophys. Res., 115, C12002, doi:12010.11029/12010JC006460, 2010.

Chen, Y.: Groundwater analysis in the watershed downstream of Hanjiang along the coast of Yue Dong, Guangdong water resources and hydropower, 31-32, 2008 (in Chinese).

Dagg, M., Dai, M., Harrison, P., and Rabouille, C.: Introduction, Cont. Shelf Res., 28, V-VI, 2008.

Dai, M., Zhai, W., Cai, W., Callahan, J., Huang, B., Shang, S., Huang, T., Li, X., Lu, Z., Chen, W., and Chen, Z.: Effects of an estuarine plume-associated bloom on the carbonate system in the lower reaches of the Pearl River estuary and the coastal zone of the northern South China Sea, Cont. Shelf Res., 28, 1416-1423, doi:10.1016/j.csr.2007.04.018, 2008.
Das, P., Marchesiello, P., and Middleton, J. H.: Numerical modelling of tide-induced residual circulation in Sydney Harbour, Mar. Freshwater. Res., 51, 97-112, 2000.

Delhez, E. J. M., Deleersnijder, E., Mouchet, A., and Beckers, J.M.: A note on the age of radioactive tracers, J. Mar. Res., 38, 277-286, 2003.

Dulaiova, H. and Burnett, W. C.: Are groundwater inputs into river-dominated areas important? The Chao Phraya River-Gulf of Thailand, Limnol. Oceanogr., 51, 2232-2247, 2006.

Gan, J., Cheung, A. Y. Y., Guo, X., and Li, L.: Intensified upwelling over a widened shelf in the northeastern South China Sea, J. Geophys. Res., 114, C09019, doi:09010.01029/02007JC004660, 2009a.

Gan, J., Li, L., Wang, D., and Guo, X.: Interaction of a river plume with coastal upwelling in the northeastern South China Sea, Cont. Shelf Res., 29, 728-740, 2009b.

Gan, J., Lu, Z., Dai, M., Cheung, A. Y. Y., Liu, H., and Harrison, P.: Biological response to intensified upwelling and to a river plume in the northeastern South China Sea: A modeling study, J. Geophys. Res., 115, C09001, doi:10.1029/2009JC005569, 2010.

Garcia-Solsona, E., Garcia-Orellana, J., Masque, P., and Dulaiova, H.: Uncertainties associated with Ra-223 and Ra-224 measurements in water via a Delayed Coincidence Counter (RaDeCC), Mar. Chem., 109, 198-219, 2008.

Garcia-Solsona, E., Garcia-Orellana, J., Masqué, P., Rodellas, V., Mejías, M., Ballesteros, B., and Domínguez, J. A.: Groundwater and nutrient discharge through karstic coastal springs (Castelló, Spain), Biogeosciences, 7, 2625-2638, doi:10.5194/bg-7-26252010, 2010.

Giffin, C., Kaufman, A., and Broecker, W.: Delayed coincidence counter for the assay of actinon and thoron, J. Geophys. Res., 68, 1749-1757, 1963.

Gu, H., Moore, W. S., Zhang, L., Du, J., and Zhang, J.: Using radium isotopes to estimate the residence time and the contribution of submarine groundwater discharge (SGD) in the Changjiang effluent plume, East China Sea, Cont. Shelf Res., 35, 95-107, 2012.

Guo, X., Cai, W.-J., Zhai, W., Dai, M., Wang, Y., and Chen, B.: Seasonal variations in the inorganic carbon system in the Pearl River (Zhujiang) estuary, Cont. Shelf Res., 28, 1424-1434, 2008.

Han, A., Dai, M., Gan, J., Kao, S.-J., Li, Q., Wang, L., Zhai, W., Cai, P., and Huang, B.: Nutrient dynamics in a large continental shelf system under the influence of both a river plume and coastal upwelling, Limnol. Oceanogr., 57, 486-502, 2012.

Hancock, G. J., Webster, I. T., Ford, P. W., and Moore, W. S.: Using $\mathrm{Ra}$ isotopes to examine transport processes controlling benthic fluxes into a shallow estuarine lagoon, Geochim. Cosmochim. Acta, 64, 3685-3699, 2000.

Hancock, G. J., Webster, I. T., and Stieglitz, T. C.: Horizontal mixing of Great Barrier Reef waters: Offshore diffusivity determined from radium isotope distribution, J. Geophys. Res., 111, C12019, doi:10.1029/2006JC003608, 2006.

Hiroshi, N. and Emery, K. O.: Sediments of Shallow Portions of East China Sea and South China Sea, Geol. Soc. Am. Bull., 72, 731-762, 1961.

Hu, C. M., Muller-Karger, F. E., and Swarzenski, P. W.: Hurricanes, submarine groundwater discharge, and Florida's red tides, J. Geophys. Res., 33, L11601, doi:10.1029/2005GL025449, 2006. 
Johannes, R. E.: The ecological significance of the submarine discharge of ground water, Mar. Ecol. Prog. Ser., 3, 365-373, 1980.

Kelly, R. P. and Moran, S. B.: Seasonal changes in groundwater input to a well-mixed estuary estimated using radium isotopes and implications for coastal nutrient budgets, Limnol. Oceanogr., 47, 1796-1807, 2002.

Kim, G., Kim, J.-S., and Hwang, D.-W.: Submarine groundwater discharge from oceanic islands standing in oligotrophic oceans: Implications for global biological production and organic carbon fluxes, Limnol. Oceanogr., 56, 673-682, 2011.

Krest, J. M., Moore, W. S., and Rama: ${ }^{226} \mathrm{Ra}$ and ${ }^{228} \mathrm{Ra}$ in the mixing zones of the Mississippi and Atchafalaya Rivers: indicators of groundwater input, Mar. Chem., 64, 129-154, 1999.

Lee, Y. W. and Kim, G.: Linking groundwater-borne nutrients and dinoflagellate red-tide outbreaks in the southern sea of Korea using a Ra tracer, Estuar. Coast. Shelf S., 71, 309-317, 2007.

Lee, Y. W., Kim, G., Lim, W. A., and Hwang, D. W.: A relationship between submarine groundwater-borne nutrients traced by $\mathrm{Ra}$ isotopes and the intensity of dinoflagellate red-tides occurring in the southern sea of Korea, Limnol. Oceanogr., 55, 1-10, 2010.

Li, Y.-H., Mathieu, G., Biscaye, P., and Simpson, H. J.: The flux of ${ }^{226} \mathrm{Ra}$ from estuarine and continental shelf sediments, Earth Planet. Sci. Lett, 37, 237-241, 1977.

Liao, X. Y., Liang, J., Lao, W. B., Zhou, M. X., and Liu, H. D.: Groundwater Resources of China-Guangdong Province, edited by: Zhang Z. and Li L., The Map of China Publishing House, Beijing, China, 81 pp., 2005 (in Chinese).

Liu, G.-S., Huang, Y.-P., Chen, M., Qiu, Y.-S., Cai, Y.-H., and Gao, Z.-Y.: Specific activity and distribution of natural radionuclides and ${ }^{137} \mathrm{Cs}$ in surface sediments of the northeastern South China Sea, Acta Oceanologica Sinica, 23, 76-84, 2001 (in Chinese).

Luo, Y., Lao, H., and Wang, L.: A preliminary study on the surface sediment types and their grain size characteristics of the northeastern part of the South China Sea, Tropical Oceanology, 4, 33 41, 1985 (in Chinese).

Marsh, J. A.: Terrestrial inputs of nitrogen and phosphorus on fringing reefs of Guam, in: Proceedings of the 2nd International Coral Reef Symposium, I, Great Barrier Reef Committee, Brisbane, Australia, 332-336, 1977.

Moore, W. S.: Sampling ${ }^{228}$ Ra in the deep ocean, Deep-Sea Res., 23, 647-651, 1976.

Moore, W. S.: Radium isotope measurements using germanium detectors, Nucl. Instrum Meth B., 223, 407-411, 1984.

Moore, W. S.: Ages of continental shelf waters determined from ${ }^{223} \mathrm{Ra}$ and ${ }^{224} \mathrm{Ra}$, J. Geophys. Res., 105, C9, 22117-22122, 2000a.

Moore, W. S.: Determining coastal mixing rates using radium isotopes, Cont. Shelf Res., 20, 1993-2007, 2000 b.

Moore, W. S.: Sources and fluxes of submarine groundwater discharge delineated by radium isotopes, Biogeochemistry, 66, 7593, 2003.

Moore, W. S.: Radium isotopes as tracers of submarine groundwater discharge in Sicily, Cont. Shelf Res., 26, 852-861, 2006.

Moore, W. S.: Seasonal distribution and flux of radium isotopes on the southeastern US continental shelf, J. Geophys. Res., 112, C10013, doi:10.1029/2007JC004199, 2007.

Moore, W. S.: Fifteen years experience in measuring ${ }^{224} \mathrm{Ra}$ and ${ }^{223} \mathrm{Ra}$ by delayed-coincidence counting, Mar. Chem, 109, 188-
197, 2008.

Moore, W. S.: The Effect of Submarine Groundwater Discharge on the Ocean, Annu. Rev. Mar. Sci., 2, 59-88, 2010a.

Moore, W. S.: A reevaluation of submarine groundwater discharge along the southeastern coast of North America, Global Biogeochem. Cy., 24, GB4005, doi:10.1029/2009GB003747, 2010b.

Moore, W. S. and Arnold, R.: Measurement of ${ }^{223} \mathrm{Ra}$ and ${ }^{224} \mathrm{Ra}$ in coastal waters using a delayed coincidence counter, J. Geophys. Res., 101, 1321-1329, 1996.

Moore, W. S. and Krest, J.: Distribution of ${ }^{223} \mathrm{Ra}$ and ${ }^{224} \mathrm{Ra}$ in the plumes of the Mississippi and Atchafalaya Rivers and the Gulf of Mexico, Mar. Chem., 86, 105-119, 2004.

Moore, W. S., Key, R. M., and Sarmiento, J. L.: Techniques for precise mapping of ${ }^{226} \mathrm{Ra}$ and ${ }^{228} \mathrm{Ra}$ in the ocean, J. Geophys. Res., 90, 6983-6994, 1985.

Moore, W. S., Blanton, J. O., and Joye, S. B.: Estimates of flushing times, submarine groundwater discharge, and nutrient fluxes to Okatee Estuary, South Carolina, J. Geophys. Res., 111, C09006, doi:10.1029/2005JC003041, 2006.

Moore, W. S., Sarmiento, J. L., and Key, R. M.: Submarine groundwater discharge revealed by Ra-228 distribution in the upper Atlantic Ocean, Nat. Geosci., 1, 309-311, 2008.

Mulligan, A. E. and Charette, M. A.: Intercomparison of submarine groundwater discharge estimates from a sandy unconfined aquifer, J. Hydrol., 327, 411-425, 2006.

Peterson, R. N., Burnett, W. C., Taniguchi, M., Chen, J., Santos, I. R., and Ishitobi, T. : Radon and radium isotope assessment of submarine groundwater discharge in the Yellow River delta, China, J. Geophys. Res., 113, C09021, doi:10.1029/2008JC004776, 2008a.

Peterson, R. N., Burnett, W. C., Taniguchi, M., Chen, J., Santos, I. R., and Misra, S.: Determination of transport rates in the Yellow River-Bohai Sea mixing zone via natural geochemical tracers, Cont. Shelf Res., 28, 2700-2707, 2008b.

Pilson, M. E. Q.: On the residence time of water in Narragansett Bay, Estuaries, 8, 2-14, 1985.

Rasmussen, L. L.: Radium Isotopes as Tracers of Coastal Circulation Pathways in the Mid-Atlantic Bight, Ph.D. thesis, Massachusetts Institute of Technology Woods Hold Oceanographic Institution, Woods Hole, Massachusetts, 214 pp., 2003.

Sanford, L., Boicourt, W., and Rives, S.: Model for estimating tidal flushing of small embayments, J. Waterw. Port C., 118, 635-654, 1992.

Santos, I. R., Burnett, W. C., Chanton, J., Mwashote, B., Suryaputra, I. G. N. A., and Dittmar, T.: Nutrient biogeochemistry in a Gulf of Mexico subterranean estuary and groundwater-derived fluxes to the coastal ocean, Limnol. Oceanogr., 53, 705-718, 2008.

Shu, Y. Q., Wang, D. X., Zhu, J., and Peng, S. Q.: The 4-D structure of upwelling and Pearl River plume in the northern South China Sea during summer 2008 revealed by a data assimilation model, Ocean Model., 36, 228-241, doi:10.1016/j.ocemod.2011.01.002, 2011a.

Shu, Y. Q., Zhu J., Wang, D. X., and Xiao, X. J.: Assimilating remote sensing and in situ observations into a coastal model of northern South China Sea using ensemble Kalman filter, Cont. Shelf Res., 31, S24-S36, 2011b.

Swarzenski, P. W., Reich, C. D., Spechler, R. M., Kindinger, J. L., and Moore, W. S.: Using multiple geochemical tracers to characterize the hydrogeology of the submarine spring off Crescent 
Beach, Florida, Chem. Geol., 179, 187-202, 2001.

Taniguchi, M., Burnett, W. C., Cable, J. E., and Turner, J. V.: Investigation of submarine groundwater discharge, Hydrol. Process., 16, 2115-2129, 2002.
Zhang, F., Zhang, W., and Yang, Q.: Characteristics of grain size distributions of surface sediments in the eastern south china sea, Acta Sedimentol. Sin., 21, 452-460, 2003 (in Chinese). 